\title{
Teacher Perceptions of the New Mathematics and Science Curriculum: A Step Toward STEM Implementation in Saudi Arabia
}

\author{
Rehaf A. Madani ${ }^{1} \&$ Sufian Forawi ${ }^{1}$ \\ ${ }^{1}$ British University in Dubai, United Arab Emirates \\ Correspondence: Rehaf A. Madani, British University in Dubai, United Arab Emirates. E-mail: \\ Rehafmadai@gmail.com
}

Received: February19, 2019

Accepted: April 22, 2019 Online Published: May 27, 2019

doi:10.5539/jel.v8n3p202

URL: https://doi.org/10.5539/jel.v8n3p202

\begin{abstract}
STEM education has become one of the most rapidly growing sectors in educational reform globally. Whilst the program was successfully implemented in most countries, unfortunately the introduction in Saudi Arabia was not as successful due to a lack of clarity in the description of its meaning, purpose and framework of application. Although STEM is commonly recognized as a way of strengthening mathematics and science curricula, its exact implications are still unclear for any intervention or modification in any of the subjects related to science, mathematics, engineering and Technology, (STEM) implementation. In 2009, the Ministry of Education (MOE) introduced a new mathematics and science curriculum in a joint effort with Obeikan Research Development Company, as an adapted series of science and mathematics textbooks. The new adapted curricula attempt to make meaningful connection between student's lives and their educational experiences through the implementation of new teaching practices which include student centred investigation strategies and problem-based learning.
\end{abstract}

Keywords: STEM, science, technology, engineering \& math, MOE, anova, qualitative analysis, curriculum

\section{Introduction}

The purpose of this article is to investigate teacher's perceptions and instructional practises of the new mathematics and science curricula as a step towards STEM reform in the Kingdom of Saudi Arabia. The aim was to gain an insight on how teachers perceive, acknowledge and implement new teaching practices required for teaching the new curricula. Therefore, an insight in the improvements in the standards of Saudi Arabia's educational system in general and the overall quality of its students in the fields of mathematics and science in specific is considered. The gap regarding the failure of importance of teachers' perceptions and views in the literature regarding educational matters can be addressed by taking assistance of pertinent Saudi Arabia's literature to formulate future policy (Oyaid, 2009). Moreover, it also provided new information related to considerable issues to the Ministry of Education (MOE); so that, it can address future educational research, reform, policies as well as recommendations. The educational environment in Saudi Arabia is strongly focused on individual subject orientation, academic achievement, testing and emphasis on the basics (MOE, 2010).

Regardless of the way that the new curriculum endeavours to make instructions more life orientated, it is difficult to perceive how STEM programming will benefit and be incorporated with such useful subjects. The focus is on teachers' roles in curricular reform and the effect their perceptions carries, on their daily classroom practices. In Saudi Arabia, the educational system is a central system taking a hierarchy structure, with high authorities in the Ministry of Education and lower authorities in schools. Mathematics and science curricula in the context of this study, is set with relevant material sourced from the Ministry of Education, where teachers have no role in curriculum development nor have the authority to alter or change any topic or subject (Al-Sulaimani, 2010). Alyami (2014) argued that reform concepts and development projects require the acceptance of the affected division. Policy makers believe that change is achieved by changing the structure, however, in reality change can only be achieved by changing the subjects involved within the procedure. The success of reform measures in education is threatened, if they are not developed through debate and clarified through participatory democratic processes. Stalling's (1998) highlighted teacher's roles in the involvement and interactions of curricular reformation, emphasizing on the importance of understanding the nature of the proposed change to achieve success. However, teachers' perceptions and beliefs that shape their practices in 
implementing curricular reform are usually neglected. A study indicated a gap related to teachers' perceptions and beliefs that shape their practises in actualizing curriculum reform (Bin-Salamah, 2001).

\section{Methodology}

The methodology of the study was completed by using a parallel mixed method design, including teachers interviews and class observational methods in the qualitative part of the research study, and a cross sectional questionnaire in the quantitative part which was distributed to 547 high school mathematics and science teachers in different regions in Saudi Arabia in order to address the following research questions: What are the major aspects of the new mathematics and science curricula as a form of STEM education implementation in Saudi Arabia? What are the perceptions of teachers on the implementation of the newly adapted science and mathematics curricula? How is the newly adapted mathematics and science curricula delivered in the classrooms, as a form of STEM education? the qualitative method was first applied using basic interpretative studies.

\section{Sampling; Target Population}

The quantitative part of the research study, consisted of 543 highschool mathematics and science teachers. Sample selection was decided on by using $10 \%$ of the target population, including male and female high school mathematics and science teachers, teaching the new mathematics and science curricula within the 13 different regions of Saudi Arabia, to ensure the validity of the results from both genders. Furthermore, it was also ensured that different subgroups are represented in the sample according to their presence in population (Muijs, 2011). In the K.S.A. (Ministry of Education Report, 2013), the sample should be around 600 male and female teachers teaching high school mathematics and science subjects within the different regions in Saudi Arabia; but only 543 were suitable for analysis. 60 samples were excluded from the analysis due to missing data, teachers teaching subjects other than mathematics and science. Moreover, some teachers were teaching elementary levels, where the focus was on high school curricula. The illustration for participants' distribution in Saudi Arabia, along with the male/female ratio was proposed using a pie-chart (Figure 1). The illustration has shown that $58 \%$ participants were female teachers, while $42 \%$ were male. The alpha level used in determining sample size is 0.01 , as, it is considered acceptable in most educational research (Kotrlik \& Higgins, 2001).

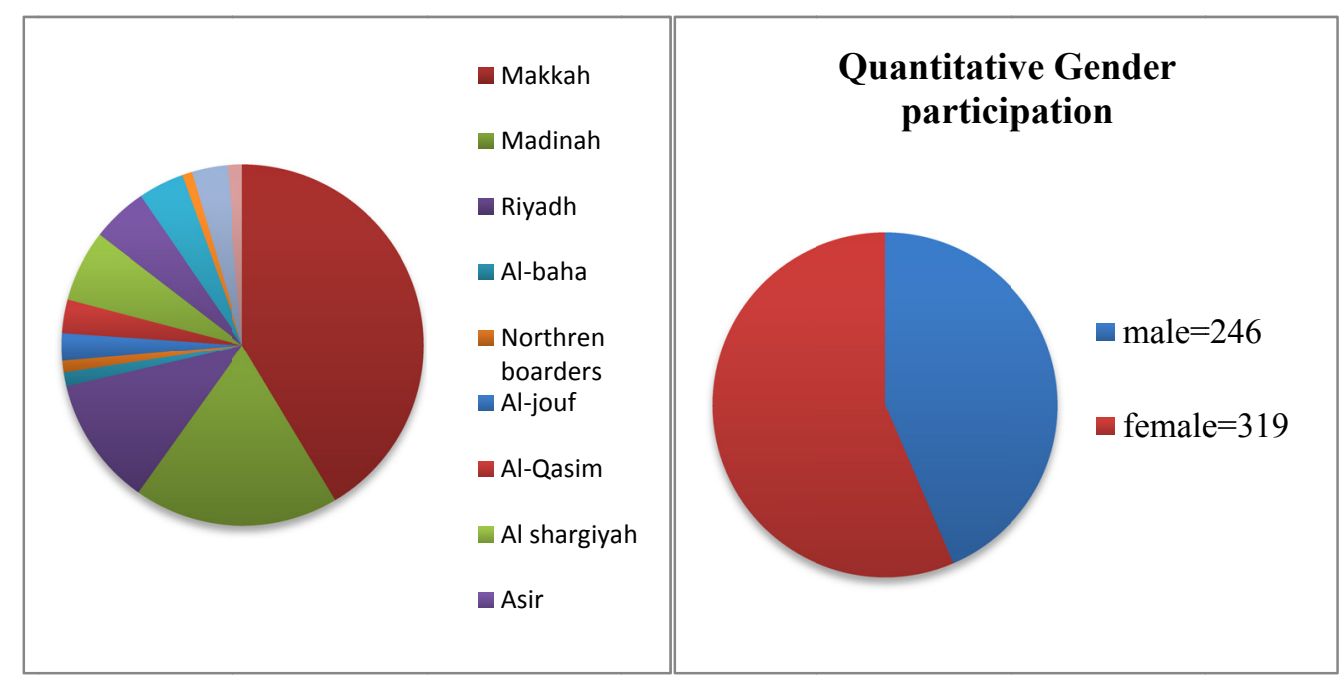

Figure 1. Quantitative sample gender and regional distribution

\section{Quantitative Analysis}

\subsection{Cross Sectional Questionnaire}

A cross-sectional questionnaire was developed as a suitable form of method to gather data. The developed questionnaire contained a series of multiple questions with five open-ended questions at the end. The researcher generated the questions in relevance to the scope of the research topic, literature review, theoretical framework and the nature of the proposed research questions. Research revealed that teachers play a key role in academic reform, and on students' educational outcomes. Scholars have suggested various factors related to teachers' 
characteristics that affect the academic performance of students in STEM courses, such as their qualification, age, experience, and gender (Etsy, 2005). In order to investigate teachers' perceptions on the new mathematics and science curricula and its implementation practices, as a step towards STEM education in Saudi Arabia, five demographic variables that might carry an effect on teachers, were taken into consideration. Including teachers' gender, nationality, years of teaching experience, educational qualifications and subjects taught.

By the use of a homogenous convenience sampling (McMillan, 2004; Glesne, 2011), a onetime questionnaire was distributed among different schools in Saudi Arabia, to analyse the perceptions of a large group of participants. The group included high school mathematics and science teachers, teaching the new mathematics and science curricula implemented in Saudi Arabia (Rea \& Parker, 2012; Fraenkel et al., 2015). Furthermore, it was also used to understand applied teaching strategies required for teaching the new mathematics and science curricula and its relevance to teaching practices required for STEM education implementation. Hanson et al. (2005) described questionnaires as a valuable tool to understand how education is functioning in a certain area by capturing useful snapshots of educational efforts.

The questionnaire was developed with the addition of five open-ended questions at the end, to minimize the limitations of the developed questionnaire and maximize its benefits. This would help gain a more in-depth response and give the participants a place to voice their perceptions freely and clearly (Rattray \& Jones, 2007). Moreover, several points including; confidentiality of participants, rights to withdraw at any time, potential of the research to improve participant's educational situation and the degree of threat or sensibility of the developed questions were carefully taken into considerations by the researcher (Cohen, Manion, \& Morrison, 2013).

The cross-sectional questionnaire contained a selection of forty-two items (Appendix A), as described by De Vaus (2002) within a suitable range of questions in a questionnaire. It mostly contained close-ended questions with five open-ended questions at the end. All questions used within the questionnaire constituted to the nature of the research questions and the data of the research understudy (Creswell, 2013). Due to the uniqueness of the research study, the quantitative measurement of the subjects' responses to the research questions required the development of the instruments by the researcher. The questionnaire was designed into five sections. The first section involved an overview of the demographic information of participants including gender, years of teaching experience, nationality, subjects taught and teachers' educational qualifications. The second section covered teacher's background including how teachers are prepared to teach the newly applied mathematics and science curricula as a step towards STEM implementation in Saudi Arabia. Further on, the third section was related to the perceptions of teachers regarding to the objective of this study. The fourth section comprises of teaching the new mathematics and science curricula within the classroom, it includes teacher's preparedness, collaboration, development, the new curriculum efficacy as well as the challenges and barriers. The fifth section on the other hand, consisted of five open-ended questions that were analysed as a form of a qualitative method. The open-ended questions were only included in the manually distributed questionnaires as the aim was to facilitate the online process for the participants from the 13 different regions in Saudi Arabia. The manually distributed questionnaires were distributed to male and female high schools in Jeddah and Al-Medina cities in Saudi Arabia, due to convenience factors.

The developed questionnaire may be in the initial image of the three middle sections, which had been prepared in the form of multiple-choice questions. Based on the objective of the research study, each dimension of questions included partial sets of variables. In the first section, questions 6 to 18, the aim was to investigate teachers' awareness and preparedness levels to teach the new mathematics and science curricula. Therefore, participants were offered the following options: $1=$ not prepared, $2=$ somewhat prepared, $3=$ well prepared and $4=$ very well prepared. The second part, including questions 19 to 29 , aimed to investigate the emphasis of the new mathematics and science curricula on teachers' implementation practices. Options included; $1=$ no emphasis, 2 $=$ minimal emphasis, $3=$ moderate emphasis and $4=$ heavy emphasis. In the third section, questions $30-39$, the objective was to investigate the delivery of the new mathematics and science curricula in the classroom, options included; 1 = no opinion, 2 = disagree, $3=$ somewhat agree and $4=$ strongly agree.

In the developed questionnaire, participants were provided with four options to choose from. A careful examination was taken into consideration when developing the questions as a mixture of both positively and negatively worded options were proposed in all the three middle sections of developed questionnaire. It was distributed through the following options in the form of "strongly agree or disagree, not prepared and very well prepared, no emphasis and heavy emphasis" to minimize the threat for biases (Rattray \& Jones, 2007). Furthermore, the use of neutral options or mid points on the scale were also offered in the form of "minimal emphasis, somewhat agree, somewhat prepared". Forcing agreement or disagreement through eliminating a mid-point or neutral option within the proposed options can force participants to claim "no opinion" when they 
actually have one. It is due to the fact that some respondents have no bases for choosing between agreement and disagreement; therefore, providing a neutral option that can be used as a safe choice in order to avoid unpopular viewpoints that can later on, affect the results of the research (John, 2005; Williams et al., 2015). Adding to that, participants' responses were later translated into numerical data to form statistical analysis.

Table 1. Expressing items of the developed questionnaire for each dimension, in the three middle sections in the form of multiple choice

\begin{tabular}{|c|c|c|c|c|c|}
\hline \multirow[t]{2}{*}{ Questions } & \multirow[t]{2}{*}{ Dimensions } & \multicolumn{4}{|c|}{ Questionnaire Answer Options } \\
\hline & & 1 & 2 & 3 & 4 \\
\hline Questions 6 to 18 & Teacher Background & Not prepared & Somewhat prepared & well prepared & Very well prepared \\
\hline Questions 19 to 29 & Teachers' perception & None & Minimal emphasis & Moderate emphasis & Heavy emphasis \\
\hline Questions 30 to 39 & $\begin{array}{l}\text { Teaching New Math and Science } \\
\text { Subjects in a Classroom }\end{array}$ & No opinion & Disagree & Somewhat agree & Strongly agree \\
\hline
\end{tabular}

Due to the fact that the context of the research study is based on Saudi Arabia, where Arabic is known as the first language, a translation of the instrument into Arabic was required to ensure the validity and accuracy of the distributed questionnaire. Two of the criteria were taken into account for translating the instrument. A first criterion was related to the correlation of Arabic and English language's meaning. Second was related to the clarity of the translation offered to the participants (Fraenkel et al., 2015). The Arabic version was tested using two different professional translators in order to ensure the sense of the items had not been lost in translation. The first translator used mostly difficult scientific terminologies that made the survey seem complicated and rigid. The second translator on the other hand, did minor modifications to facilitate the translation by using simpler wording. This resulted in making it easier for the participants to accurately respond. Moreover, a back translation of the Arabic version of the questionnaire was achieved in order to confirm that no meaning was lost in translation.

Two experienced educators in Saudi Arabia helped in reviewing the layout of the questionnaire including translation, clarity, wording issues, relevance to the research topic, and the quality of the developed questions (Simon, 2011). The second step was done by piloting the questionnaire in a sample of sixty teachers from both genders, teaching higher grades mathematics and science subjects, using a homogeneous convenience sampling. Sample size of the pilot study was decided by using $10 \%$ of the 600 participants required for the quantitative part of the research study, as it was described earlier in participants' selection. The cross-sectional questionnaires were distributed manually among different high schools of both genders in Jeddah, Saudi Arabia (Kotrlik \& Higgins, 2001).

To test the trustworthiness of the applied instrument as a mean of gathering data, the developed questionnaire was tested for its validity and reliability through the use of multiple tests. Tavakol and Dennick (2011) described validity and reliability as two fundamental elements in assessing the development of a questionnaire. Moreover, they clarified that the trustworthiness of an instrument is allied with its validity, where an instrument cannot be valid unless it is considered as reliable. Validity is an assessment to investigate whether an instrument measures up to its objectives. In this research study, the validity of the developed questionnaire was ensured through the use of construct validity test, using the approximation discrimination approach.

Reliability on the other hand, is concerned with the ability of an instrument to measure consistently when measurements are repeated using the same tools under the same circumstances (Tavakol \& Dennick, 2011). The researcher calculated the reliability coefficient achievement test through the application of two different tests. First, the use of Cronbach's alpha coefficients test; also known as the most popular test to measure reliability (Tavakol \& Dennick, 2011; Rattray \& Jones, 2007). Secondly, by the use of Kuder-Richardson 21 test, as an imitative test to Cronbach's alpha, also known as a measurement of internal consistency (Kuder \& Richardson, 1937, Appendix A refers).

\subsection{Data Analysis and Results}

The statistical means of the quantitative data were analysed using descriptive statistics in the quantitative part of the study; such as percentages, group means, modes, frequencies, T-test of differences and F-test of analysis of variance (ANOVA) by using the Statistical Packages for Social Science (SPSS 22.0) to perform the data analysis (Muijs, 2011). Data analysis began with data cleaning and descriptive statistics for the rate of investigating teachers' perceptions and classroom practices regarding new mathematics and science curricula as a step towards the implementation of STEM education in Saudi Arabia. Furthermore, the examination of the differences among 
the five demographic variables, including participants': gender, years of teaching experience, nationality, educational qualifications and the subject taught. In order to guarantee confidentiality and anonymity, all participating subjects were assured that any data collected from them will be held confidential as each participant will be referred to a number instead of using his or her original identity (Fraenkel \& Wallen, 1993).

\section{Quantitative Results}

A cross-sectional questionnaire was employed to collect data from teacher's responses. Further, the descriptive and inferential statistical analysis was achieved, including: demographics, t-test and ANOVA test.

\subsection{Teachers' Cross Sectional Questionnaire}

The purpose of the cross-sectional questionnaire was to investigate teachers' perceptions of the new mathematics and science curricula as a step towards STEM implementation in Saudi Arabia. In order to analyse the data, statistical package for social sciences (SPSS) version 22.0 was used. The data cleaning and subsequent analysis was performed in order to analyse the perceptions of a large group of science and mathematics teachers, teaching high school students the new mathematics and science curricula within different regions of Saudi Arabia.

In the questionnaire, 543 participants were included, which consisted of both male and female teachers. The participants were those teaching high school mathematics and science subjects within different regions of Saudi Arabia. Data analysis began with data cleaning and descriptive statistics for the rate of investigating teachers' perceptions of the new mathematics and science curricula as a step towards STEM education implementation in Saudi Arabia. A frequency distribution was generated for each question in order to allow visual inspection for out-of-range data, missing values and input errors (Creswell, 2005). An examination of the differences among five demographic variables, including: participant's gender, years of teaching experience, nationality, educational qualification and the subject taught were applied.

\subsection{Descriptive Statistical Analysis}

The cross-sectional questionnaire contained a selection of 42 items, which were categorized into five sections. The first section involved an overview of the demographic information of participants including gender, years of teaching experience, nationality, subjects taught and teachers' educational qualifications. The second section covered teachers' background that entailed how teachers are prepared to teach the newly applied mathematics and science curricula as a step towards STEM implementation in Saudi. The third section presented teachers' perception in regards to the emphasis placed on the newly implemented mathematics and science curricula on students' learning outcomes. The forth section, encompassed teaching the new mathematics and science curricula in the classroom including teachers' preparedness, collaboration, development and efficacy of the new curricula, and any challenges that the industry faces. The fifth section on the other hand, consisted of five open-ended questions that were analysed as a form of qualitative method.

The three middle parts of the developed questionnaire aimed for investigating teachers' backgrounds, perceptions and finally, teaching the new mathematics and science curricula within the classroom. Mean scores (M) and standard deviation (SD) were used to report the answers for these questions among 34 statements. Participants five demographic variables were considered in each part of the questionnaire including: participants' gender, years of teaching experience, nationality, educational qualifications and the subject taught. An independent sample t-test was used to test the statistical significance for participants' gender and years of teaching experience. Whereas, a one-way ANOVA was used after all ANOVA assumptions have been attained and achieved to determine the statistical significance for participants' nationality, educational qualifications and the subject taught. The conventional 2-tailed 0.05 level was used throughout the current research study, as it is considered acceptable in most educational research (Kotrlik \& Higgins, 2001).

1) The rate of awareness of the major aspects of the newly implemented mathematics and science curricula, is a step towards STEM education implementation in Saudi Arabia.

The major aspects of the newly implemented mathematics and science curriculum were demonstrated by endowing four options to the participants based on the perceptions of teaching. These perceptions were notified further to explore the implementation of the new required practices. The intended options provided to the participants were $1=$ Not prepared, $2=$ somewhat prepared, $3=$ Well prepared, $4=$ Very well prepared. The mean scores and standard deviation for the rate of awareness of the major aspects of new mathematics and science curricula are revealed in Table 8 . The perceptions of new mathematics and science curriculum are demonstrated for questions 6 to 18 . 
Table 2. Rate of awareness of the major aspects of the new mathematics and science curriculum used $(\mathrm{N}=543)$

\begin{tabular}{|c|c|c|}
\hline \multirow[t]{2}{*}{ Teacher Background } & \multicolumn{2}{|c|}{ Awareness } \\
\hline & M & $\mathrm{SD}$ \\
\hline 1) Develop students conceptual understanding of taught subject & 2.28 & 1.27 \\
\hline 2) Provide deeper coverage of fewer science/math concepts & 2.59 & .56 \\
\hline 3) Make connection between science/ mathematics with other subjects & 2.44 & 0.61 \\
\hline 4) Lead a class of students using investigative strategies & 2.48 & 0.65 \\
\hline 5) Encourage students' interest in mathematics and science subjects & 2.31 & 0.70 \\
\hline 6) Use assigned textbook as a source rather than a primary instructional tool & 2.12 & 0.73 \\
\hline 7) Connecting taught subjects with students' daily life issues & 2.53 & 0.62 \\
\hline 8) Manage a class of students engaged in hands on/ project-based activities & 2.60 & 0.60 \\
\hline 9) Teaching the new mathematics and science curriculum & 2.47 & 0.65 \\
\hline 10) How prepared are you in teaching lessons that appropriately combine STEM subjects & 2.56 & 0.63 \\
\hline 11) Apply new student-centered teaching techniques & 2.63 & 0.57 \\
\hline 12) Using teaching approaches that focuses on improving students critical thinking and problem solving & 2.45 & 0.68 \\
\hline 13) Making connections between different STEM subjects when teaching & 2.50 & 0.66 \\
\hline
\end{tabular}

The findings of Table 2 have shown teachers perceptions towards the new mathematics and science curricula in Saudi Arabia. Findings have revealed that teachers were able to implicate new teaching practices required for teaching the new mathematics and science curricula. Level of preparedness varied among different participants, none of the participants chose the not prepared option. Based on the mean scores achieved, it was revealed that teachers were well prepared in applying new student centred teaching techniques $(\mathrm{M}=2.63)$. Managing a class of students engaged in hands on project-based activities $(M=2.60)$. Providing deeper coverage of fewer mathematics and science concepts $(\mathrm{M}=2.59)$. Making connections between different STEM subjects when teaching $(\mathrm{M}=2.50)$. Connecting taught subjects with student's daily life issues $(\mathrm{M}=2.53)$ and in teaching lessons that appropriately combine STEM subjects $(\mathrm{M}=2.56)$.

When teaching the newly implemented curricula it was revealed that teachers were somewhat ready to apply new teaching instructional practices that focus on improving students critical thinking and problem-solving techniques $(\mathrm{M}=2.45)$. Teaching the new mathematics and science curricula $(\mathrm{M}=2.47)$. Lead a class of students using investigative strategies $(\mathrm{M}=2.48)$. Moreover, based on the lowest mean scores achieved, it was shown that teachers were not entirely ready to use assigned textbooks as a source rather than a primary instructional tool $(M=1.63)$. Develop student's conceptual understanding of taught subject $(M=2.28)$ and encourage students' interest in mathematics and science subjects $(\mathrm{M}=2.31)$.

Table 3. Rate of awareness of the new mathematics and science curriculum used by demographic variables $(\mathrm{N}=$ 543)

\begin{tabular}{|c|c|c|}
\hline \multirow[t]{2}{*}{ Teacher Background } & \multicolumn{2}{|c|}{ Awareness } \\
\hline & $\mathrm{M}$ & $\mathrm{SD}$ \\
\hline \multicolumn{3}{|l|}{ Gender } \\
\hline Male $(\mathrm{n}=168)$ & 2.67 & 1.29 \\
\hline Female $(\mathrm{n}=375)$ & 2.78 & 1.20 \\
\hline \multicolumn{3}{|l|}{ Years of teaching experience } \\
\hline $1-16(n=356)$ & 2.09 & .54 \\
\hline$>16(\mathrm{n}=187)$ & 3.98 & .73 \\
\hline \multicolumn{3}{|l|}{ Nationality } \\
\hline Saudi $(n=400)$ & 1.89 & .50 \\
\hline Egyptian $(\mathrm{n}=70)$ & 1.98 & .79 \\
\hline Jordan $(\mathrm{n}=30)$ & 1.76 & .53 \\
\hline Other $(n=43)$ & 1.82 & .64 \\
\hline \multicolumn{3}{|l|}{ Qualification } \\
\hline Bachelor's degree $(n=324)$ & 1.41 & .51 \\
\hline Masters $(\mathrm{n}=150)$ & 2.15 & .39 \\
\hline Other $(\mathrm{n}=69)$ & 2.16 & .39 \\
\hline \multicolumn{3}{|l|}{ Subject taught } \\
\hline Mathematics $(n=205)$ & 2.29 & 1.21 \\
\hline Chemistry $(\mathrm{n}=128)$ & 2.31 & 1.21 \\
\hline Biology $(n=100)$ & 2.30 & 1.21 \\
\hline Physics $(\mathrm{n}=110)$ & 2.31 & 1.21 \\
\hline
\end{tabular}


The above table, Table 3 demonstrated the descriptive statistics on the rate of awareness of the newly implemented mathematics and science curricula in regards to the five selected demographic variables. In respect to gender, Table 9 has shown that the awareness level of both males and females group was closely associated in their preparation of making connections between different STEM subjects when teaching. The mean score between male and female group was 2.67 and 2.78 respectively. In regards to participants' years of teaching experience, it was concluded from the mean score that teachers with experience greater than 16 years, were more capable in applying new instructional practices. Moreover, shared positive perceptions on the level of awareness in making connections between different STEM subjects when teaching the new mathematics and science curricula, with a mean score of $(\mathrm{M}=3.98)$ when compared with teachers with fewer years of teaching experience $(M=2.09)$. Furthermore, in respect to teachers' nationality, all teachers groups closely rated their awareness level of making connections between different STEM subjects when teaching, as the mean scores ranged between 1.76 and 1.89. From the findings, it was observed that teachers with higher educational degrees, when teaching the newly implemented mathematics and science curriculum mostly made the connections between different STEM subjects. The mean score was higher among teachers possessing a master's degree (M $=2.15)$ and other certificates $(\mathrm{M}=2.16)$ as compared to teachers possessing a bachelor degree $(\mathrm{M}=1.41)$. Table 3 has illustrated that the mean scores for the subject taught was closely ranged between 2.29 and 2.31 .

Table 4. T-test table for the group difference on participants' gender and years of teaching experience

\begin{tabular}{llllll}
\hline Variable & Df & T & P & Mean Diff & SD Diff \\
\hline $\begin{array}{l}\text { Rate of awareness of newly integrated math and science } \\
\text { curriculum used/gender }\end{array}$ & 543 & 85.148 & 1.69 & 3.63 & .20 \\
$\begin{array}{l}\text { Rate of awareness of newly integrated math and science } \\
\text { curriculum used /Years of teaching experience }\end{array}$ & 543 & 1.46 & 0.03 & 3.40 & 1.64 \\
\hline
\end{tabular}

Table 4, illustrates the rate of awareness among participants with respect to their gender and years of teaching experience. Findings have shown that there ware no differences found between participants gender and the rate of awareness of newly implemented mathematics and science curricula $(t=85.148, p>.05)$. On the contrary, in regards to participant's years of teaching experience, the $t$-test indicated that there were statistical differences between the two groups: $\mathrm{t}=1.46, p<.05$. Results have revealed that teachers with higher teaching experience $>$ 16 were more capable and qualified on teaching the new mathematics and science curricula along with their abilities to implement new required teaching practices when compared with teachers with lower experience.

Table 5. ANOVA table for the group difference on participants' nationalities

\begin{tabular}{lllllll}
\hline Variable & SS & Df & MS & F & P & n2 \\
\hline Between groups & 9.932 & 3 & 3.311 & 2.191 & .263 & .088 \\
Within groups & 814.503 & 539 & 1.511 & & & \\
Total & 824.435 & 542 & & & & \\
\hline
\end{tabular}

Table 4 has shown the findings obtained from the ANOVA analysis showing the mean scores of four groups of participant's nationalities; Jordanian, Saudi, Egyptian and others. ANOVA test indicated that there were no statistical differences at $\alpha=0.05$ among the four groups mean scores on the effect of participants' nationality on their level of awareness in teaching the new mathematics and science curricula $(F=2.191, p>.05)$

Table 6. ANOVA table for the group difference on teachers' qualifications

\begin{tabular}{lllllll}
\hline Variable & SS & Df & MS & F & P & П2 \\
\hline Between groups & 57.136 & 3 & 19.045 & 2.719 & 0.03 & 0.44 \\
Within groups & 3775.199 & 539 & 7.004 & & & \\
Total & 3832.335 & 542 & & & & \\
\hline
\end{tabular}

In respect to participants' qualifications, results revealed that teacher's with master and other degrees showed the largest two mean scores across participants' qualifications, while mean scores of teachers with bachelor's degree showed the least groups. In addition, the ANOVA test indicated that there were statistical differences between the mean scores on participant's qualification awareness in teaching the new mathematics and science curricula: 
$F=2.719, p<.05$.

Table 7. ANOVA \& Tukey test for the group difference on participants' subject taught

\begin{tabular}{lllllll}
\hline Variable & SS & Df & MS & F & P & n2 \\
\hline Between groups & 57.136 & 3 & 19.045 & 2.719 & 0.03 & 0.44 \\
Within groups & 3775.199 & 539 & 7.004 & & & \\
Total & 3832.335 & 542 & & & & \\
\hline
\end{tabular}

\begin{tabular}{|c|c|c|c|c|c|c|}
\hline \multicolumn{7}{|c|}{ Multiple Comparisons } \\
\hline \multirow{2}{*}{ (I) Subject Taught } & \multirow[t]{2}{*}{ (J) Subject Taught } & \multirow[t]{2}{*}{ Mean Difference (I-J) } & \multirow[t]{2}{*}{ Std. Error } & \multirow[t]{2}{*}{ Sig. } & \multicolumn{2}{|c|}{$95 \%$ Confidence Interval } \\
\hline & & & & & Lower Bound & Upper Bound \\
\hline \multirow[t]{3}{*}{ Math } & Chemistry & -.010 & .059 & .065 & -.16 & .14 \\
\hline & Biology & -.033 & .061 & .021 & -.19 & .12 \\
\hline & Physics & -.060 & .054 & .064 & -.20 & .08 \\
\hline \multirow[t]{3}{*}{ Chemistry } & Math & .010 & .059 & .034 & -.14 & .16 \\
\hline & Biology & -.023 & .069 & .030 & -.20 & .16 \\
\hline & Physics & -.051 & .063 & .038 & -.21 & .11 \\
\hline \multirow[t]{3}{*}{ Biology } & Math & .033 & .061 & .021 & -.12 & .19 \\
\hline & Chemistry & .023 & .069 & .030 & -.16 & .20 \\
\hline & Physics & -.028 & .065 & .040 & -.20 & .14 \\
\hline \multirow[t]{3}{*}{ Physics } & Math & .060 & .054 & .054 & -.08 & .20 \\
\hline & Chemistry & .051 & .063 & .030 & -.11 & .21 \\
\hline & Biology & .028 & .065 & .040 & -.14 & .20 \\
\hline
\end{tabular}

Table 7, has shown the ANOVA findings for participant's subject taught awareness. The results have illustrated statistically significant difference between the mean scores on participants subject taught awareness $(\mathrm{F}=2.719, \mathrm{p}$ $<.05)$.

The significant differences illustrated from the ANOVA tests were identified from Turkey test for teacher's perception and subjects taught. The results of multiple comparisons have shown that there were statistically significant differences between teachers' perception in mathematics and biology subjects $(p=0.021)$. Significant differences were found between biology with chemistry (0.030) and biology with physics $(0.040)$. Moreover, significant differences were found between chemistry and mathematics $(0.034)$ and between chemistry with physics (0.038).

\section{2) The rate of the implementation of the new science and mathematics curricula}

The rate of the implementation of the new mathematics and science curricula was determined by providing the participants with four different options to report their opinion in regards to the newly implemented science and mathematics curricula. Options included were as follow: $1=$ No emphasis, $2=$ Minimal emphasis, $3=$ Moderate emphasis and $4=$ Heavy emphasis. Table 14 shows the mean scores and standard deviations of STEM adoption through questions 19 to 28 of the developed questionnaire.

Table 8. The rate of participants' implementation of the new science and mathematics curricula $(N=543)$

\begin{tabular}{lll}
\hline Teachers' perception & \multicolumn{2}{c}{ Rate of Implantation } \\
\cline { 2 - 3 } & $\mathrm{M}$ & $\mathrm{SD}$ \\
\hline 19) Students interest in mathematics and science subjects & 2.75 & 1.00 \\
20) Aid in learning basic concepts in mathematics and science subjects & 2.53 & 0.86 \\
21) Aid in learning important terms and facts of knowledge & 2.68 & 0.94 \\
22) Prepare students for future study in these fields & 2.28 & 1.06 \\
23) Learn how to communicate ideas in mathematics and science subjects effectively & 2.67 & 0.93 \\
24) Prepare students for standardized tests & 2.26 & 1.51 \\
25) Learn about the relation between STEM subjects & 2.61 & 1.01 \\
26) Connect mathematics and science subjects to students' daily life issues & 2.78 & 0.99 \\
27) Make a connection between STEM subjects in problem solving & 2.39 & 1.03 \\
28) Effect on students' critical thinking and problem solving & 2.73 & 0.95 \\
\hline
\end{tabular}


Table 8 has shown the responses revealed by participating teachers with respect to the newly implemented mathematics and science curricula in the classroom. Findings have shown that all participated teachers agreed on the fact that there was some degree of emphasis on the learning and teaching process while implementing the new mathematics and science curriculum, as non-chose the no emphasis option. Participants rated the implementation of the new mathematics and science curriculum as moderate emphasis on the following aspects, where the highest mean scores were achieved through connecting mathematics and science subjects to student's daily life issues $(M=2.78)$. Moreover, on students' interest in mathematics and science subjects $(M=2.75)$ and on students' critical thinking and problem-solving techniques $(\mathrm{M}=2.73)$. Further, moderate emphasis was also achieved in the following points: Aid in learning basic concepts in mathematics and science subjects $(\mathrm{M}=2.53)$, Aid in learning important terms and facts of knowledge $(\mathrm{M}=2.68)$. Learning how to communicate ideas in mathematics and science subjects effectively $(\mathrm{M}=2.67)$ and in learning about the relation between different STEM subjects $(\mathrm{M}=2.61)$.

The lowest mean scores were achieved through the following points: participants rated the implementation as minimal emphasis on preparing students for standardized tests $(\mathrm{M}=2.26)$, for future study in the fields of mathematics and science subjects $(\mathrm{M}=2.28)$. Further, in making a connection between different STEM subjects in problem solving $(\mathrm{M}=2.39)$.

Table 9. Teachers' perceptions by demographic variables $(\mathrm{N}=543)$

\begin{tabular}{lll}
\hline Teachers' perception & \multicolumn{2}{l}{ Implementation } \\
\cline { 2 - 3 } & M & SD \\
\hline Gender & 3.41 & 1.55 \\
Male $(\mathrm{n}=168)$ & 3.29 & 1.53 \\
Female $(\mathrm{n}=375)$ & & \\
Years of teaching experience & 3.39 & 1.58 \\
$1-16(\mathrm{n}=356)$ & 3.76 & 1.49 \\
$>16(\mathrm{n}=187)$ & & \\
Nationality & 2.43 & 1.57 \\
Saudi $(\mathrm{n}=400)$ & 2.28 & 1.52 \\
Egyptian $(\mathrm{n}=70)$ & 2.47 & 1.56 \\
Jordanian $(\mathrm{n}=30)$ & 2.45 & 1.45 \\
Other $(\mathrm{n}=43)$ & & \\
Qualification & 3.39 & 1.66 \\
Bachelors $(\mathrm{n}=324)$ & 3.40 & 1.57 \\
Masters $(\mathrm{n}=150)$ & 3.78 & 1.49 \\
Other $(\mathrm{n}=69)$ & & \\
Subject taught & 3.38 & 1.68 \\
Mathematics $(\mathrm{n}=205)$ & 3.48 & 1.53 \\
Chemistry $(\mathrm{n}=128)$ & 3.58 & 1.48 \\
Biology (n=100) & 3.45 & 1.51 \\
Physics $(\mathrm{n}=110)$ &
\end{tabular}

In the above table, results demonstrated the descriptive statistics on the rate of the implementation of the new mathematics and science curriculum in regards to the five selected demographic variables. In Table 9 , the mean scores were derived for descriptive purposes and for testing on differences. In regards to gender, both male and female groups closely rated the implementation of the new mathematics and science curriculum to encourage students to use in their courses as moderate emphasis. The mean scores for the male group was $(\mathrm{M}=3.41)$ and for the female group it was $(M=3.29)$. In respect to years of teaching experience, participants with teaching experience greater than 16 years were closely to heavy emphasis with a mean value of $M=3.76$. While teachers with less than 16 years of teaching experience were closely to moderate emphasis with a mean value of $\mathrm{M}=3.39$. In regards to participants' nationality, all teachers despite their different nationalities were closed to minimal emphasis with mean values ranging between 2.28 and 2.87. The implementation of the new science and mathematics curriculum was closely associated to the heavy emphasis perception with respect to educational qualifications. Teachers with other degrees have shown higher mean score $(\mathrm{M}=3.78)$ as compared to the teachers holding master's degree $(\mathrm{M}=3.40)$. On the contrary, teachers holding bachelor's degree showed least mean score $(\mathrm{M}=3.39)$. Moreover, mean scores for the subject taught for chemistry, physics and mathematics were closely associated to moderate emphasis with mean scores ranging between $(\mathrm{M}=3.13)$ and $(\mathrm{M}=3.48)$. On the contrary, higher mean scores were shown for the teachers holding experience in biology group $(\mathrm{M}=3.58)$ since there is a close association to the heavy emphasis. 
Table 10. T-test table for the group difference on participants' gender and years of teaching experience

\begin{tabular}{llllll}
\hline Variable & Df & T & P & Mean Diff & SD Diff \\
\hline $\begin{array}{l}\text { Teachers' perception /gender } \\
\text { Teachers' perception / Years of teaching } \\
\text { experience }\end{array}$ & 543 & 1.652 & .273 & .053 & .058 \\
& 542 & 1.529 & 0.039 & .049 & .062 \\
\hline
\end{tabular}

The differences for teachers' perception were indicated in Table 10 with respect to gender and years of teaching experience. Findings have shown that there was no statistical difference between the two groups $(t=1.652$, $p>.05)$. The small variance between the two groups further revealed the insignificant statistical difference. By considering years of teaching experiences between participants, results of t-test have indicated significant difference between the two groups $(t=1.529, \mathrm{p}<.05)$. In respect to participants with teaching experience greater than 16 years, the results were shown for heavy emphasis, to assist teachers to apply new instructional practices required for teaching the new mathematics and science curriculum. Moderate emphasis has been shown among teachers with less than 16 years of teaching experience, on encouraging students to use new teaching practices required for the newly implemented science and mathematics curricula. This was also concluded from the small variance between the mean values.

Table 11. T-test table for the group difference on participants' nationalities

\begin{tabular}{llllll}
\hline Variable & Df & T & P & Mean Diff & SD Diff \\
\hline Teachers' perception / Nationality & 543 & 1.68 & 1.49 & .363 & .35 \\
\hline
\end{tabular}

The group difference between participant's nationalities was indicated from Table 11. The results have shown that there was no statistically significant difference between nationalities of teachers $(t=1.68, p>.05)$. Teachers of different nationalities shared similar perceptions in respect to the newly implemented mathematics and science curriculum and its required teaching practices.

Table 12. ANOVA \& Tukey test for the group difference on teachers' educational qualification

\begin{tabular}{lllllll}
\hline Variable & SS & Df & MS & F & P & $\boldsymbol{\eta 2}^{\mathbf{2}}$ \\
\hline Between groups & 14.89 & 5 & 2.97 & 2.890 & .02 & 0.377 \\
Within groups & 1285.23 & 537 & 59.83 & & & \\
Total & 1300.12 & 542 & & & & \\
\hline
\end{tabular}

\begin{tabular}{lllllll}
\hline $\begin{array}{l}\text { Multiple Comparisons } \\
\text { (I) }\end{array}$ & & & & & \\
& $(J)$ & Mean Difference (I-J) & Std. Error & Sig. & \multicolumn{2}{l}{$95 \%$ Confidence Interval } \\
\cline { 5 - 7 } None & & & & & Lower Bound & Upper Bound \\
& Minimal emphasis & .031 & .072 & .030 & -.16 & .22 \\
& Moderate emphasis & -.039 & .068 & .073 & -.21 & .14 \\
Minimal emphasis & Heavy emphasis & .063 & .070 & .020 & -.12 & .24 \\
& None & -.031 & .072 & .038 & -.22 & .16 \\
& Moderate emphasis & -.070 & .056 & .027 & -.21 & .07 \\
Moderate emphasis & None & .032 & .059 & .046 & -.12 & .18 \\
& Minimal emphasis & .070 & .068 & .075 & -.14 & .21 \\
Heavy emphasis & Heavy emphasis & .102 & .056 & .003 & -.07 & .21 \\
& None & -.063 & .053 & .021 & -.03 & .24 \\
& Minimal emphasis & -.032 & .070 & .080 & -.24 & .12 \\
& Moderate emphasis & -.102 & .059 & .046 & -.18 & .12 \\
\hline
\end{tabular}

Results have showed that teachers possessing a master's degree with other higher educational degrees were closely associated around the heavy emphasis with respect to educational qualification variable. Higher mean was notified among teachers with other degree $(\mathrm{M}=3.78)$ as compared to the teachers holding master's degree $(\mathrm{M}=3.40)$. However, the mean score for teachers holding bachelor's degree was the lowest $(\mathrm{M}=3.39)$. Table 12 has shown the statistical differences between educational qualification awareness on the implementation of the new mathematics and science curricula. Results have shown statistically significant difference between the 
mean scores of educational qualification awareness and the newly implemented curricula and it instructional practices $(\mathrm{F}=2.890, \mathrm{p}<.05)$.

The significant differences illustrated from the ANOVA tests were identified from Tukey test for teacher's perception and implementations of the new mathematics and science curricula. The results of multiple comparisons have shown that there was statistically significant difference between teacher's perception and minimal emphasis $(p=0.046)$ as compared to moderate emphasis $(p=0.021)$. On the contrary, the results from multiple comparisons have shown statistical difference between minimal and moderate emphasis $(p=0.027)$.

Table 13. ANOVA table for the group difference on participants' subject taught

\begin{tabular}{lllllll}
\hline Variable & SS & Df & MS & F & P & n2 \\
\hline Between groups & 8.06 & 3 & 2.68 & 2.191 & .263 & .405 \\
Within groups & 1292.06 & 539 & 2.39 & & & \\
Total & 1300.12 & 542 & 5.07 & & & \\
\hline
\end{tabular}

In regards to the participant's subject taught, results of the mean scores were between 3.02 and 3.58. In addition, the ANOVA test indicated there were no differences among the four subjects' mean scores (chemistry, biology, physics and mathematics) on participant's awareness on the implementation of the new mathematics and science curricula and its required instructional practices when teaching: $F=2.191, p>.05$.

\section{3) Rate of the newly adapted mathematics and science curricula's delivery in the classrooms}

Table 14 demonstrated the mean scores and standard deviations of teaching the new mathematics and science curricula in the classroom. By providing the participants with four options to report their perceptions regarding classroom practices, the adaption rate of the new mathematics and science curriculums employed was identified. The included options were: $1=$ no opinion, $2=$ disagree, $3=$ somewhat agree, $4=$ strongly agree.

Table 14. Rate of adapted mathematics and science curriculum delivery in the classrooms $(\mathrm{N}=543)$

\begin{tabular}{lcl}
\hline Teaching the New Math and Science Subjects in a Classroom & Adapted \\
\cline { 2 - 3 } & M & SD \\
\hline 29) Teachers are well prepared and equipped to teach the new math/science curriculum & 2.40 & 1.03 \\
30) Teachers on your school regularly observe each other's classes as a part of sharing and improving instructional & 2.87 & 0.91 \\
strategies & 2.80 \\
31) The new Math and science curriculum is contributed to STEM education & 0.93 \\
32) Teachers' development programs and workshops were offered before new curriculum implementation & 1.63 \\
33) The new curriculum offers students better learning opportunities & 2.74 \\
34) The new curriculum is more relevant to students lives and 21century demands & 3.05 \\
35) The new curriculum is considered as an improvement in Saudi Arabia's education & 0.99 \\
36) The new curriculum challenges students by offering complex problems related to real-world scenarios & 2.99 \\
37) STEM education has been integrated as something other than adding additional science and mathematics & 0.94 \\
instruction/courses into your school & 2.92 & 0.94 \\
\hline
\end{tabular}

The above table revealed teachers' perceptions on teaching the new mathematics and science curricula in the classroom. The above table concluded that all participants placed their opinions, as none chose the 'no opinion' option. Teachers somewhat agree on the fact that STEM education has been integrated as something other than adding additional science and mathematics instructional courses in schools $(\mathrm{M}=2.82)$. Teachers regularly observed each other's classes as a part of sharing and improving instructional strategies $(\mathrm{M}=2.87)$. The fact that the new mathematics and science curriculum is contributed to STEM education $(\mathrm{M}=2.80)$. From results, the highest mean scores were achieved in the following points, where participant teachers strongly agreed on the fact that the new curriculum is more relevant to students' lives and 21st century demands $(\mathrm{M}=3.02)$, The new curriculum is considered as an improvement in Saudi Arabia's education $(M=2.99)$ and that the new curriculum challenges students by offering complex problems related to real-world scenarios $(\mathrm{M}=2.92)$. The lowest mean scores on the other hand, revealed that teachers did not fully agree on the fact that teacher' development programs and workshops were offered as a requisite before the new mathematics and science curriculum was implemented $(\mathrm{M}=1.63)$. Moreover, on the fact that teachers are well prepared and equipped to teach the new mathematics and science curriculum $(\mathrm{M}=2.40)$ and that the new curriculum offers students better learning opportunities $(\mathrm{M}=2.74)$. 
Table 15. Rate of the newly adapted mathematics and science curriculum delivery in the classrooms used by Demographic variables $(\mathrm{N}=543)$

\begin{tabular}{lll}
\hline Teaching the New Mathematics and Science Subjects in a Classroom & \multicolumn{2}{c}{ Adapted } \\
\cline { 2 - 3 } & $\mathrm{M}$ & $\mathrm{SD}$ \\
\hline Gender & 2.89 & 1.23 \\
Male $(\mathrm{n}=168)$ & 2.69 & 1.25 \\
Female $(\mathrm{n}=375)$ & & \\
Years of teaching experience & 2.59 & .56 \\
$1-16(\mathrm{n}=356)$ & 3.97 & .69 \\
$>16(\mathrm{n}=187)$ & & \\
Nationality & 1.95 & .54 \\
Saudi $(\mathrm{n}=400)$ & 1.65 & .76 \\
Egyptian $(\mathrm{n}=70)$ & 1.83 & .54 \\
Jordanian $(\mathrm{n}=30)$ & 1.88 & .66 \\
Other $(\mathrm{n}=43)$ & & \\
Qualification & 2.41 & .61 \\
Bachelor's degree $(\mathrm{n}=324)$ & 3.54 & .67 \\
Masters $(\mathrm{n}=150)$ & 3.86 & .53 \\
Other $(\mathrm{n}=69)$ & & \\
Subject taught & 3.97 & .56 \\
Mathematics $(\mathrm{n}=205)$ & 3.21 & .52 \\
Chemistry $(\mathrm{n}=128)$ & 2.45 & .51 \\
Biology $(\mathrm{n}=100)$ & 1.90 & .73 \\
Physics $(\mathrm{n}=110)$ & & \\
\hline
\end{tabular}

In the above Table 15, results demonstrated the descriptive statistics on the delivery rate of the newly adapted mathematics and science curricula in the classrooms, in regards to the five demographic variables. In Table 15, the mean scores were derived for descriptive purposes and for testing on differences. With respect to gender, both male and female groups closely rated their adapted level of using new teaching practices required for the delivery of the new mathematics and science curricula to their students in the classrooms. The mean score for male teachers was 2.89 and 2.69 for females. In respect to participants' years of teaching experience, teachers with experience greater than 16 years shared positive feedback on the implementation of new teaching practices required for the implementation of the new mathematics and science curricula, as a step toward STEM education $(M=3.97)$ when compared with teachers with less years of teaching experience $(M=2.49)$. In respect to participants' nationality, all teachers despite their different origins shared similar feedback on the implementation of new classroom instructional practices, with mean scores ranged between 1.65 and 1.95. In regards to participants educational qualifications, teachers holding a master's degree $(M=3.54)$ and other higher certificates $(\mathrm{M}=3.86)$ shared similar perceptions in adapting required teaching methods for the implementation of the new mathematics and science curricula in different STEM subjects when teaching, when compared with participants holding a bachelor's degree $(\mathrm{M}=2.41)$. Finally, in respect to participant's subject taught, results of the mean scores were between 1.90 and 3.97. The largest two mean scores across the subjects taught were obtained representing the teacher's results for teaching mathematics, chemistry and biology. However, the mean scores for teachers teaching physics showed the least group.

Table 16. T-test table for the group difference on participants' gender and years of teaching experience

\begin{tabular}{llllll}
\hline Variable & Df & T & P & Mean Diff & SD Diff \\
\hline $\begin{array}{l}\text { Rate of adapted math and science curriculum delivery in the classrooms } \\
\text { used/gender }\end{array}$ & 543 & 1.675 & .265 & .067 & .058 \\
$\begin{array}{l}\text { Rate of adapted math and science curriculum delivery in the classrooms } \\
\text { used/Years of teaching experience }\end{array}$ & 543 & 1.78 & 0.04 & 3.50 & 1.67 \\
\hline
\end{tabular}

The group difference among participant's gender and years of teaching experience was demonstrated using t-test (Table 16). The results have indicated statistically insignificant difference between the groups $(t=1.675$, $\mathrm{p}>.05)$. The difference was shown for the newly implemented science and mathematics curriculum in the classroom. Small variance between the mean values further indicated insignificant difference between both groups. The findings of the t-test have shown that there was statistically significant difference between two groups with respect to years of teaching experience $(\mathrm{t}=1.78, p<.05)$. Positive feedback was shared by teachers holding greater than 16 years' experience and thus, revealed more qualified to implement new teaching 
instructions required for teaching the new mathematics and science curricula. This was also concluded from the small variance between the mean values.

Table 17. ANOVA table for the group difference on participants' nationality

\begin{tabular}{lllllll}
\hline Variable & SS & Df & MS & F & P & n2 \\
\hline Between groups & 9.952 & 3 & 3.311 & 2.421 & .233 & .078 \\
Within groups & 834.403 & 539 & 1.511 & & & \\
Total & 814.465 & 542 & & & & \\
\hline
\end{tabular}

The group difference between participant's nationalities was indicated from Table 17. The results have shown that there was no statistically significant difference between nationalities of teachers $(F=2.421, p>.05)$.

Table 18. ANOVA \& Tukey test for the group difference on participants' educational qualification

\begin{tabular}{|c|c|c|c|c|c|c|c|}
\hline Variable & SS & $\mathrm{Df}$ & MS & \multicolumn{2}{|l|}{$\mathrm{F}$} & $\mathrm{P}$ & $\eta^{2}$ \\
\hline Between groups & 54.150 & 3 & 18.285 & \multirow{3}{*}{\multicolumn{2}{|c|}{2.659}} & 0.04 & 0.49 \\
\hline Within groups & 2795.199 & 539 & 8.005 & & & & \\
\hline Total & 2849.349 & 542 & & & & & \\
\hline \multicolumn{8}{|c|}{ Multiple Comparisons } \\
\hline \multirow{2}{*}{$\begin{array}{l}\text { (I) Educational } \\
\text { Qualification }\end{array}$} & \multirow{2}{*}{\multicolumn{2}{|c|}{$\begin{array}{l}\text { (J) Educational } \\
\text { Qualification }\end{array}$}} & \multirow{2}{*}{$\begin{array}{l}\text { Mean Difference } \\
(\mathrm{I}-\mathrm{J})\end{array}$} & \multirow{2}{*}{$\begin{array}{l}\text { Std. } \\
\text { Error }\end{array}$} & \multirow[t]{2}{*}{ Sig. } & \multicolumn{2}{|c|}{ 95\% Confidence Interval } \\
\hline & & & & & & Lower Bound & Upper Bound \\
\hline \multirow[t]{2}{*}{ Bachelors } & Maste & & .032 & .081 & .033 & -.18 & .24 \\
\hline & Other & & .082 & .177 & .023 & -.37 & .54 \\
\hline \multirow[t]{2}{*}{ Masters } & Bache & & -.032 & .081 & .033 & -.24 & .18 \\
\hline & Other & & .050 & .192 & .040 & -.44 & .54 \\
\hline \multirow[t]{2}{*}{ Other } & Bache & & -.082 & .177 & .023 & -.54 & .37 \\
\hline & Maste & & -.050 & .192 & .040 & -.54 & .44 \\
\hline
\end{tabular}

Table 18 has shown the mean scores between educational qualification and subject taught. The results have shown mean scores ranged between $(\mathrm{M}=2.41)$ and $(\mathrm{M}=4.54)$. Higher mean scores have been shown among teachers holding masters and other educational degrees with respect to qualification factor. On the contrary, the results have shown least mean scores for teachers holding bachelor's degree. Table 24 has further shown statistical differences between the qualification awareness. The results have shown that there was significant statistical difference between qualification awareness mean scores $F=2.659, p<.05$. The findings of Tukey test have shown significant difference between bachelors and masters with respect to educational qualifications. Further, the results have shown a statistically significant difference between masters and others $(p=0.040)$, masters and bachelors $(\mathrm{p}=0.33)$ and bachelors and others $(\mathrm{p}=0.023)$.

Table 19. ANOVA \& Tukey test for the group difference on participants' subject taught

\begin{tabular}{|c|c|c|c|c|c|c|c|}
\hline Variable & SS & $\mathrm{Df}$ & MS & \multicolumn{2}{|c|}{ F } & $\mathrm{P}$ & $\eta 2$ \\
\hline Between groups & 57.136 & 3 & 19.04 & & 2.719 & 0.03 & 0.44 \\
\hline Within groups & 3775.199 & 539 & \multicolumn{3}{|c|}{7.004} & & \\
\hline Total & 3832.335 & 542 & & & & & \\
\hline \multicolumn{8}{|c|}{ Multiple Comparisons } \\
\hline \multirow[t]{2}{*}{ (I) } & \multirow[t]{2}{*}{ (J) } & \multirow{2}{*}{\multicolumn{2}{|c|}{ Mean Difference (I-J) }} & \multirow[t]{2}{*}{ Std. Error } & \multirow[t]{2}{*}{ Sig. } & \multicolumn{2}{|c|}{ 95\% Confidence Interval } \\
\hline & & & & & & Lower Bound & Upper Bound \\
\hline \multirow[t]{3}{*}{ No opinion } & Disagree & .028 & & .081 & .986 & -.18 & .24 \\
\hline & Somewhat Agree & .150 & & .068 & .126 & -.03 & .33 \\
\hline & Strongly Agree & $.284^{*}$ & & .074 & .001 & .09 & .48 \\
\hline \multirow[t]{3}{*}{ Disagree } & No opinion & -.028 & & .081 & .986 & -.24 & .18 \\
\hline & Somewhat Agree & .122 & & .060 & .179 & -.03 & .28 \\
\hline & Strongly Agree & $.256^{*}$ & & .067 & .001 & .08 & .43 \\
\hline Somewhat & No opinion & -.150 & & .068 & .126 & -.33 & .03 \\
\hline \multirow[t]{2}{*}{ Agree } & Disagree & -.122 & & .060 & .179 & -.28 & .03 \\
\hline & Strongly Agree & $.134^{*}$ & & .051 & .044 & .00 & .26 \\
\hline Strongly & No opinion & $-.284^{*}$ & & .074 & .001 & -.48 & -.09 \\
\hline \multirow[t]{2}{*}{ Agree } & Disagree & $-.256^{*}$ & & .067 & .001 & -.43 & -.08 \\
\hline & Somewhat Agree & $-.134^{*}$ & & .051 & .044 & -.26 & .00 \\
\hline
\end{tabular}


Mean scores were ranged between $(M=1.25)$ and $(M=3.97)$ with respect to STEM subject taught. Higher mean scores were identified among teachers teaching chemistry, biology and mathematics subject as compared to the least mean scores notified for the physics subject. Table 25 has shown the indication of statistical differences between implementing new mathematics and science subjects and subject taught awareness. The results have shown statistically significant difference between mean scores of implementing new mathematics and science curricula and subject taught awareness $(\mathrm{F}=2.719, \mathrm{p}<.05)$. The significant differences illustrated from the ANOVA tests were identified from Tukey test for subjects and implementation of the new subject. The results of multiple comparisons have shown that there was a statistically significant difference between disagree and strongly agree perception $(p=0.001)$ as compared to strongly agree and somewhat agree $(p=0.044)$.

\section{Discussion of Quantitative Results}

The discussion is particularly cantered on the results achieved from the quantitative analysis portion of this research. The section is described in a comprehensive manner in order to give explicit meaning to these acquired results. These obtained results are also further discussed and compared with the results of studies in the past within the same area of study. Additionally, the results were compared to the tested hypothesis generated from the qualitative part of the research study to reflect how a better understanding of wider teacher perception can influence the implementation of STEM. This comparison was made to allow for a better comprehension of the convictions of large groups of science and mathematics teachers regarding the implementation of the new mathematics and science curricula in Saudi Arabia. The results were compared, analysed, and interpreted to determine if the new mathematics and science curricula are considered as a positive step towards STEM education implementation in Saudi Arabia.

From the study's results, it can be concluded that teachers started to apply new instructional practices and are gradually becoming more confident and familiar with their application. Further, STEM education helped teacher's feel more confident with the new mathematics and science curricula's requisites. Results show teachers' have a positively perceived ability to manage a class of students engaged in hands on project-based activities. In chemistry class, the teacher engaged 11th and 12th grade students in hands on class activities in multiple classes. From the results, it can be concluded that teachers were well prepared to implement new instructional practices which were found to be related to STEM instructional practices.

\subsection{Rate of Teachers' Preparation to Teach the New Mathematics and Science Curricula}

In respect to teachers' preparation to teach the new mathematics and science curriculum as a step towards the implementation of STEM education in Saudi Arabia, participants' views were investigated through questions 6 to 18 of table 8 in the cross-sectional questionnaire. These questions explored teachers' backgrounds and awareness of the new curriculum as well as their familiarity with ways to implement these into the classroom

\subsubsection{Gender}

According to the results, participants' gender did not carry a statistically significant effect on teacher preparation levels; mean scores of both genders closely rated the well-prepared option (Table 5). Moreover, findings from Table 10 have shown that there were no statistical differences found between participants' gender and the rate of preparedness of newly implemented mathematics and science curricula $(t=85.148, p>.05)$. Results revealed that teacher's gender had no effect on students' impact of knowledge; teachers' qualifications were considered as the major influential factor for students' academic performance across gender (Owolabi \& Adebayo, 2012).

\subsubsection{Educational Qualification}

This was relevant with the research study's results in respect to the effect of participants' qualifications on the level of their preparedness to teach the new mathematics and science curricula. Results of Table 6 revealed that teachers with Master's $(M=2.15)$ and other degrees $(M=2.16)$ showed the largest two mean scores across participants' qualifications, which was closest to the somewhat prepared option. The mean scores of teachers with Bachelor's degrees indicates they are the group $(\mathrm{M}=1.41)$ most likely to choose the not prepared option. In addition, the ANOVA test indicated statistical differences between the mean scores on participants' qualification awareness in teaching the new mathematics and science curricula $(\mathrm{F}=2.719, \mathrm{p}<.05)$.

\subsubsection{Teaching Experience}

On the contrary, in regards to participant's years of teaching experience, the t-test indicated that there were statistical differences between the two groups: $\mathrm{t}=1.46, \mathrm{p}<.05$. Results revealed that teachers with higher teaching experience $(>16)$ along with their abilities to implement new required teaching practices were more capable and qualified to teach the new mathematics and science curricula when compared to teachers with less experience. 
Moreover, highly experienced teachers shared positive perceptions on the level of awareness in making connections between different STEM subjects and on the application of the new teaching practices required for the implementation of the new mathematics and science curricula as a step toward STEM education.

In respect to nationality, ANOVA test (Table 11) indicated that there were no statistical differences found between participants' nationalities and their preparation to teach the new mathematics and science curricula $(\mathrm{F}=$ $2.191, \mathrm{p}>.05$ ). Results suggested that their academic background and their cultural perspectives influenced their beliefs, their ability to increase student proficiency, and their overall teaching experience (Lin, 2002).

Despite the relation between teachers' background and nationality on their teaching practices found in prior research, insignificant results achieved in this research study can be due to the fact that all participated teachers came from similar backgrounds. Almost all of the participants had nationalities that mostly consisted of Middle Eastern countries that carry similar social, cultural, and religious customs, beliefs, and practices.

\subsubsection{Subject Taught}

In respect to the subject taught, Table 7 has illustrated that the mean scores for the subject taught, which was closely associated with the somewhat prepared option, ranges between 2.29 and 2.31. Moreover, the ANOVA test indicates statistical significance between mathematics, chemistry, and biology subjects for a teacher's rate of awareness on how to implement new curriculum, such as in STEM education. Teachers' capability to connect taught subjects with students' daily life, issues, and experiences sees the highest mean value on the questionnaire. Participant interviews based on class observational methods show that the new mathematics and science curricula aim to make taught subjects relevant in a real-world context.

\subsubsection{Teacher Self-Evaluation}

Based on background demographics, participants' questionnaire responses in Table 2 show mean scores ranging between 1.63 and 2.63, with teachers' responses mostly consisting of somewhat prepared and well prepared. None of the results indicated that teachers were not prepared to teach the new mathematics and science curricula, yet it was concluded that none felt very well prepared to do so. Most responses were in the middle, which indicated that teachers are starting to adapt to the new curriculum and to its new required instructional practices. This was found to be relevant with participants' interviews, when teachers shared mixed views on teachers' qualifications to teach the new mathematics and science curricula and implement new instructional practices. Results also revealed that teachers were somewhat prepared to: develop students' conceptual understanding depending on the subject taught $(\mathrm{M}=2.28)$; encourage students' interest in mathematics and science subjects ( $\mathrm{M}$ $=2.31)$; teach the new mathematics and science curriculum $(\mathrm{M}=2.4)$; encourage students' interest in mathematics and science subjects $(\mathrm{M}=2.31)$; lead a class of students using investigative strategies $(\mathrm{M}=2.48)$; and make a connection between science and mathematics with other subjects $(\mathrm{M}=2.44)$.

The lowest mean scores recorded indicated that teachers were not entirely ready to use assigned textbooks as a source rather than a primary instructional tool $(\mathrm{M}=1.63)$. These results mimic the participant's interview responses when they were asked, "Do you believe teachers are qualified to teach the new mathematics and science curricula?" Throughout the results, it has been concluded that responses from the participants showed that teachers were not highly qualified for applying new instructional practices.

However, these instructional practices were required from the Ministry of Education to teach new mathematics and science curricula. Results revealed that teachers felt well prepared in applying new student cantered teaching techniques, with the highest mean value of all the variables $(\mathrm{M}=2.63)$. Teachers also felt prepared: managing a class of students engaged in hands on project based activities $(\mathrm{M}=2.60)$; connecting taught subjects with student's daily life issues $(\mathrm{M}=2.53)$; making connections between different STEM subjects when teaching $(\mathrm{M}=$ $2.50)$; teaching lessons that appropriately combine STEM subjects $(\mathrm{M}=2.56)$; and providing a deeper coverage of fewer mathematics and science concepts $(\mathrm{M}=2.59)$.

\subsubsection{Benefits of Being Prepared for STEM}

From the study's results, it can be concluded that teachers started to apply new instructional practices and are gradually becoming more confident and familiar with their application. Further, STEM education helped teacher's feel more confident with the new mathematics and science curricula's requisites. Results show teachers' have a positively perceived ability to manage a class of students engaged in hands on project-based activities. In chemistry class, the teacher engaged 11 th and 12 th grade students in hands on class activities in multiple classes. From the results, it can be concluded that teachers were well prepared to implement new instructional practices which were found to be related to STEM instructional practices. Roberta (2015) described the STEM way of learning as an ability to promote students' critical thinking on how STEM concepts, ideas, standards, and 
practices are associated with daily life experiences.

\subsection{The Rate of the Implementation of the New Science and Mathematics Curricula}

This section of the discussion covers the portion of the questionnaire in which participants were asked to rate the emphasis on their classroom implementation practices of the new mathematics and science curricula as a step towards STEM implementation in Saudi Arabia, as seen in items 19 through 28 (Table 8). This was achieved with relevance to participants' five demographic variables that might have carried an impact on their implementation, including gender, years of teaching experience, qualifications, nationality, and the subject taught.

\subsubsection{Gender}

In respect to gender, mean scores of both genders revealed moderate emphasis on their perception of new implementation practices (Table 9). However, no statistical difference was shown between the two groups $(t=$ $1.652, p>.05)($ Table 10).

\subsubsection{Teaching Experience}

In respect to participants years of teaching experience, it was revealed that teachers with more than 16 years of teaching were rated as perceiving the need for a heavy emphasis on implementing new instructional practices required from the Ministry of Education to teach the new mathematics and science curricula. On the contrary, teachers with less than 16 years of experience rated moderate emphasis (Table 11). Further, results of a t-test have indicated significant difference between the two groups $(\mathrm{t}=1.529, p<.05)$ (Table 16).

\subsubsection{Educational Qualification}

In regards to teachers' educational qualifications, it was concluded from the mean scores achieved that teachers with Bachelor's and Master's degrees were placed in the moderate emphasis category, while teachers' holding other educational certificates rated a heavy emphasis (Table 9). Additionally, ANOVA test scores (Table 12) have shown a statistically significant difference between participants' educational qualification and applied instructional practices of the newly implemented curricula $(F=2.890, p<.05)$. Ugbe $(2000)$ investigated the influence of teachers' qualifications and experience on students' academic performance of students taught by qualified teachers in contrast with students taught by unqualified teachers

\subsubsection{Nationality}

In terms of participants' nationalities, all participants rated their perception of the need for implementation as minimal emphasis; moreover, a t-test indicated no statistical significance between different nationalities (Table $11)$.

\subsubsection{Subject Taught}

In regards to subjects taught, mathematics, chemistry, and physics teachers rated their perception levels for the need to implement STEM practices with a moderate emphasis, while biology teachers rated a close to heavy emphasis. Further, an ANOVA test indicated there was no significance on perceptions of applying new instructional practices with subjects taught.

\subsubsection{Perceptions on Process Success}

Analysing table 8 , which shows responses to questions 19 through 28, the mean scores of participants' responses was between 2.26 and 2.78 which mean ranging between minimal emphasis and moderate emphasis. It can be concluded that all participants agreed to the fact that they perceived some degree of emphasis on the learning and teaching process when implementing the new mathematics and science curricula; none of the participants chose the no emphasis option. This indicated that the new mathematics and science curricula have affected the process of teaching through the implementation of new instructional practices but still, it hasn't taken over old teaching methods.

\subsection{Rate of Teachers' Satisfaction with STEM Education and Its Delivery in the Classroom}

In this section of the questionnaire, participants were asked to state their opinion on the new mathematics and science curriculum as a step towards STEM implementation in Saudi Arabia, as seen in items 29 through 37 (Table 14). These was filtered, as in part one and part two of the discussion, with participants' five demographic variables that might have carried an impact on their perceptions and implementation practices, including: gender, years of teaching experience, qualifications, nationality and the subject taught. It was concluded from teachers' responses to that all participants placed their opinions, as none chose the "No" opinion option. 


\subsubsection{Gender}

In respect to gender, t-test results (Table 22) have indicated a statistically insignificant difference between the two groups $(\mathrm{t}=1.675, \mathrm{p}>.05)$.

\subsubsection{Teaching Experience}

In regards to participants' years of teaching experience, it was revealed that teachers with more than 16 years of experience shared positive opinions on the new mathematics and science curricula, rating it closely to the strongly agree category. On the contrary, teachers with less than 16 years of experience closely rated their opinions to somewhat agree (Table 15). Further, results of a t-test (Table 16) have indicated a significant difference between the two groups $(\mathrm{t}=1.78, p<.05)$.

\subsubsection{Educational Qualifications}

In regards to teachers' educational qualifications, ANOVA test scores (Table 18) have shown a statistically significant difference between participants' educational qualification and their opinions on the newly implemented curricula (scores $F=2.659, p<.05$ ).

\subsubsection{Nationality}

In terms of participants' nationalities, ANOVA test results have shown that there were no statistically significant differences found between nationalities $(\mathrm{F}=2.421, \mathrm{p}>.05)$

\subsubsection{Subject Taught}

In regards to subjects taught, mathematics, chemistry and physics rated their awareness levels as moderate emphasis while in biology it was close to heavy emphasis. Further, ANOVA test shows a statistically significant difference between mean scores of implementing new mathematics and science curricula and subject taught $(\mathrm{F}=$ $2.719, \mathrm{p}<.05)$.

\subsubsection{Teacher Development Programs}

Furthermore, results achieved revealed the following: teachers disagreed on the fact that teacher development programs and workshops were offered before the implementation of the new curriculum, showing the lowest mean value $(\mathrm{M}=1.63)$. These results support the qualitative results of this study, where teachers were asked about if they believed that development and teacher preparation programs are required.

\subsubsection{Failures}

Participants disagreed on the fact that teachers are well prepared and equipped to teach the new mathematics and science curricula $(\mathrm{M}=2.40)$. This was corresponding to participant's interview responses, as most of the participants described teachers as unqualified to apply new instructional practices required for a successful implementation of the new mathematics and science curriculum.

\subsubsection{Successes}

Results further revealed that teachers somewhat agreed on the following: the new curricula offered students better learning opportunities $(\mathrm{M}=2.74)$; the new curriculum is considered as an improvement in Saudi Arabia's education $(\mathrm{M}=2.99)$; the new curriculum challenges students by offering complex problems related to real-world scenarios $(\mathrm{M}=2.92)$; STEM education has been integrated as something other than adding additional science and mathematics instruction/courses into your school $(\mathrm{M}=2.82)$; teachers at your school regularly observe each other's classes as a part of sharing and improving instructional strategies $(\mathrm{M}=2.87)$; and the new mathematics and science curriculum is contributed to STEM education $(\mathrm{M}=2.80)$. These obtained quantitative results correspond to participants' interview results when teachers were asked about the major aspects of the new mathematics and science curricula. Most of the results were equivalent to those obtained from the qualitative method portion of the research, including teacher's interviews, class observational methods, and the open-ended questions included at the end of the distributed questionnaire.

\section{Recommendations}

The outcomes and results of the research study have important implications to enhance the STEM education practical implication in the schools of Saudi Arabia. The results acquired from the qualitative and quantitative methods have showed extensive and strong evidence that these results would assist in comprehending the major role that teachers play within the educational reform and its implementation. Achieved results provided a window to the applied teaching strategies and the weak spots that needs focus for future support and assistance. Recommendations related to research identified several areas of research to improve the impact and diffusion of STEM education innovations in Saudi Arabia. Due to the lack of supporting studies available in Saudi Arabia, 
more research is recommended to provide conclusive vision of the new mathematics and science curricular reform. Firstly, a call for more regional research is necessary to improve scientific educational systems to keep up with the rapid development pace needed as Saudi Arabia is considered far behind. This exploration study ought to be imitated to affirm its discoveries where additionally inquire about should be done in other geographic areas and crosswise over other STEM orders to recognize whether the techniques distinguished in this review are like those discovered somewhere else. Furthermore, it has been observed that there is very little research regarding the coherence between mathematics and science subjects in the attained curriculum, where more research is required to investigate how curricular coherence works for students.

Moreover, work should be performed on how students perceive and observe these connections. Additionally, the introduction of Reformed Education approaches through professional development programs and workshops. Reformed education is about recruiting and adequately preparing teachers with both the content knowledge and the pedagogical content knowledge necessary to implement specific teaching strategies needed to effectively teach their content. Additionally, inadequate understanding about inquiry instruction, complexity of the approach, and educational significance to future educators and STEM professionals provide justification for offering and investigating inquiry-based STEM professional development. This development would be useful for faculty members teaching mathematics and science subjects in all school levels. The utilization of subjective research strategies in concentrate integrative practices ought to be expanded to permit specialists to investigate at more prominent profundity the marvels encompassing integrative techniques. In this manner, scientists are managed a wealthier record of occasions and more prominent understanding into an exceptionally complex instructional process.

In regards to practice, additional investments by the authorities in optimizing interactivity and collaboration among mathematics and science teachers are required. It could be in the form of an educational platform that brings together curricular developers, trainers, and teachers to provide resources and reference sources for best practice regarding STEM reform in the kingdom. Furthermore, research is required for redesigning and the restructuring of teachers' development programs and workshops with the addition of STEM training and implementation practices. Moreover, the enhancement of mathematics and science teachers' participation in workshops and professional development programs especially those that prepare teachers to design and implement integrative STEM and improving instructional practices. Furthermore, coordination among teachers, who are teaching different STEM disciplines in schools, should be enhanced and encouraged in order to achieve successful STEM implementation.

Recommendations related to the field of education, findings have suggested that more effort to increase public awareness on STEM education and strategies needed for promoting its adoption and implementation. In order to legislate, STEM education in Saudi Arabia, additional correlation and reorganization among topics within individual STEM subjects are required. Reorganization of the new mathematics and science curricula should be proceeded in a way where the topics between different STEM subjects are in sequence and consistent with each other. Furthermore, the development of professional development programs and workshops need to be restructured to fit the educational needs, standards and be as beneficial as possible to match the objective and purpose of the new mathematics and science curricula. It can then be introduced as a form of STEM education implementation in Saudi Arabia, where more focus is required on the addition of STEM training. Also, in order to attain teachers' participation in faculty development and teaching related endeavours, educational institutions as the Ministry of Education and school heads should value such efforts. This can be achieved by motivating faculty members that additional time they spend on developing new instructional strategies will be accounted for annual reviews, raises, promotions and tenure. As well, there is a need to develop a unified documented tool to investigate instructional practices occurring in the classroom, as a form of assessment and quality control. At the same time, further research is required for developing the ways to aid or assist teachers to cater association among different STEM subjects.

\section{Conclusion}

STEM implementation, results revealed that there is still a lack of clarity on what STEM should look like. STEM educational pathway stands for a better understanding of the world everyone lives in, including social standings, economic wealth, and a healthy lifestyle (Hall et al., 2011). This research study further informed the developing literature on STEM education by helping scholars understand the factors that facilitate and hinder teachers from implementing integrated mathematics and science curricular materials. Equally important, findings showed that the biggest barrier of implementing STEM education in Saudi Arabia is not as a result of the lack of knowledge about effective teaching practices rather, it is a result of inadequate knowledge on how to effectively spread and apply the use of currently available and tested research-based instructional strategies. Moreover, the intention is 
to provide teachers with an experiential understanding on how to apply and use new teaching practices as an instructional framework that could shape up STEM education implementation in Saudi Arabia.

Several points were concluded from investigating mathematics and science teachers' perceptions of the new mathematics and science curriculum as a step towards the implementation of STEM education. Firstly, a successful STEM implementation is necessary to occur along with a transformation in teacher's part from acting as transmitters of information to that of facilitators of learning. Therefore, helping students recognize relevant sources of knowledge to solve real world problems. Secondly, administrators, who are keen on interdisciplinary STEM programs, need to encourage teachers' professional development programs and competency with new instructional approaches by creating strong structures and instruments. In addition, administrators must perceive the internal and external barriers that teachers face when attempting to actualize an innovative approach and provide encouragement; support and professional development activities that help them overcome these barriers.

Finally, more research is required to investigate new instructional approaches that are required for the success of the new mathematics and science curricula; hence it results in STEM implementation in Saudi Arabia. Several points were concluded from investigating mathematics and science teachers' perceptions of the new mathematics and science curriculum as a step towards the implementation of STEM education. As the true potential of STEM education reform lays in the opportunity to affect change in teacher practice. Coordinated STEM training is an approach that expands on characteristic associations between STEM subjects for the goal of advancing students' comprehension of each discipline by expanding on students' previous knowledge. Results concluded from qualitative and quantitative analysis demonstrated that instructional practices required for teaching new mathematics and science curricula from the Ministry of Education, were equivalent to those required for the implementation of STEM education. In order to overcome the barriers of STEM implementation in Saudi Arabia, the Ministry of Education needs to increase the exposure of STEM concept among students and teachers at all levels.

\section{References}

Abul-Fadl, M. (1988). Islam as a force of global cultural renewal. The American Journal of Islamic Social Sciences, 5(2), 165.

Adeyemi, B. (2010). Teacher related factors as correlates of pupils' achievement in social studies in South West Nigeria. Electronic Journal of Research in Educational Psychology, 8(1), 313-332.

Ahsan, M., Shahed, A., \& Ahmad, A. (2013). Islamization of knowledge: An agenda for Muslim intellectuals. Global Journal of Management and Business Research, 13(10), 1-11.

Aikenhead, G. (2006). Science education for everyday Life: Evidence-based practice. New York: Teachers College Press.

Aikenhead, G., \& Ryan, A. (1992). Students' perceptions about the epistemology of science. Science Education, 76(6), 559-580. https://doi.org/10.1002/sce.3730760602

Alabdulkareem, S. (2004). Investigating science teachers' beliefs about science and science teaching: struggles in implementing science education in Saudi. Ed.D. Dissertation. West Virginia University.

Al-Alwani, A. (2005). Barriers to integrating information technology in Saudi Arabia science education. Ph.D. Thesis. University of Kansas.

Al-Ghamdi, A., \& Al-Salouli, M. (2013). Saudi elementary school science teachers' beliefs: Teaching science in the new millennium. International Journal of Science and Mathematics Education, 11(2), 501-525. https://doi.org/10.1007/s10763-012-9353-0

Al-Ghanem, G. (1999). Reforming science education in Saudi Arabia: A conceptual framework for the design of coordinated and thematic science (CATS) Module for Grades 7-9. Ph.D. Thesis. University of West Virginia.

Al-khaldi, S. (2007). Education Policies in the GCC States. Dubai: Gulf Research Center, Research Paper Series.

Allamnakhrah, A. (2013). Learning critical thinking in Saudi Arabia: Student perceptions of secondary pre-service teacher education programs. Journal of Education and Learning, 2(1), 197-210. https://doi.org/10.5539/jel.v2n1p197

Almannie, M. (2015). Cases Encountered: The Development of Public Education in Saudi Arabia. International Conference on Trends in Social Sciences and Humanities (TSSH-2015) August Bali, Indonesia.

Almazroa, H. (2013). Professional development: A vision for Saudi science teachers. Esera.org. 
Almazroa, H., \& Al-Shamrani, S. (2015). Saudi Science Teacher Professional Development. In Science Education in the Arab Gulf States (pp. 3-21). Boston: Sense Publishers. https://doi.org/10.1007/978-94-6300-049-9_1

Almazroa, H., Aloraini, A., \& Alshaye, F. (2015). Science and math teacher's perceptions of professional development within the new science curriculum implementation. The Annual Conference of The National Association for Research in Science Teaching (NARST), Chicago, IL, USA.

Al-Miziny, H. (2010). Abdicating of education in Saudi Arabia (1st ed.). Beirut: Arab Diffusion Company.

Al-Mohannadi, A., \& Capel, S. (2007). Stress in physical education teachers in Qatar. Social Psychology of Education, 10(1), 55-75. https://doi.org/10.1007/s11218-006-9004-9

Alrwathi, E., Almazroa, H., Alahmed, N., Scantbly, C., \& Alshaye, F. (2014). Exploring curriculum implementation: Focus on science teaching. The 2nd History, Philosophy, and Science Teaching Asian Regional Conference. Taipei City, Taipei.

AL Sadaawi, A. (2010). Saudi national assessment of educational progress (SNAEP). International Journal of Education Policy and Leadership, 5(11), 1-14. https://doi.org/10.22230/ijepl.2010v5n11a202

Alshamrani, S. (2012). Priorities of research in science education in Saudi Arabia. Journal of Educational Sciences and Islamic Studies, 24(1), 128-199.

Al Shannag, Q., Tairab, H., Dodeen, H., \& AbdelFattah, F. (2013). Linking teachers' quality and student achievement in the kingdom of Saudi Arabia and Singapore: The impact of teachers' background variables on student achievement. Journal of Baltic Science Education, 12(5), 652-665.

Al-Sulaimani, (2010). The importance of teachers in integrating ICT into science teaching in intermediate schools in Saudi Arabia: A mixed methods study. Ed.D Dissertation, RMIT University.

Alyami, R. (2014). Educational reform in the kingdom of Saudi Arabia: Tatweer schools as a unit of development. Literacy Information and Computer Education Journal, 5(2), 1424-1442. https://doi.org/10.20533/licej.2040.2589.2014.0202

Anderson, R., \& Helms, J. (2001). The ideal of standards and the reality of schools: Needed research. Journal of Research in Science Teaching, 3-16. https://doi.org/10.1002/1098-2736(200101)38:1<3::AID-TEA2>3.0.CO;2-V

Ary, D., Jacobs, L., Sorensen, C., \& Walker, D. (2013). Introduction to research in education. New York: Cengage Learning.

Ashgar, A., Ellington, R., Rice, E., Johnson, F., \& Prime, G. (2012). Supporting STEM education in secondary science contexts. Interdisciplinary Journal of Problem-based Learning, 6(2), 85-125. https://doi.org/10.7771/1541-5015.1349

Asunda, P. (2011). Open courseware and STEM initiatives in career and technical education. Journal of STEM Teacher Education, 48(2), 6-37. https://doi.org/10.30707/JSTE48.2Asunda

Avery, Z., \& Reeve, E. (2013). Developing effective STEM professional development programs. Journal of Technology Education, 25(1), 55-69. https://doi.org/10.21061/jte.v25i1.a.4

Badri, M., Alnuaimi, A., Mohaidat, J., Al Rashedi, A., Yang, G., \& Al Mazroui, K. (2016). My science class and expected career choices - a structural equation model of determinants involving Abu Dhabi high school students. International Journal of STEM Education, 3(1), 12-23. https://doi.org/10.1186/s40594-016-0045-0

Baker, L. (1994). Doing social research (2nd ed.). New York: McGraw-Hill Inc.

Baker, S., Edwards, R., \& Doidge, M. (2012). How many qualitative interviews is enough? Expert voices and early career reflections on sampling and cases in qualitative research. Working paper. Brighton University.

Baki, R. (2004). Gender-segregated education in Saudi Arabia: Its impact on social norms and the Saudi labor market. Education Policy Analysis Archives, 12(28), 28. https://doi.org/10.14507/epaa.v12n28.2004

Bangura, K. (2004). Tirbyi in the Muslim World, with a Focus on Saudi Arabia. Online Submission. https://doi.org/10.1016/S0969-6210(04)00182-1

Barnes, K., Marateo, R., \& Ferris, S. (2007). Teaching and learning with the net generation. Innovate: Journal of Online Education, 3(4), 1-7. 
Becker, K., \& Park, K. (2011). Integrative approaches among Science, Technology, Engineering, and Mathematics (STEM) subjects on students' learning: A Meta-analysis. Journal of STEM Education: Innovations and Research, 12(5), 23-37.

Bell, D. (2016). The reality of STEM education, design and technology teachers' perceptions: a phenomenographic study. International Journal of Technology \& Design Education, 26(1), 61-79. https://doi.org/10.1007/s10798-015-9300-9

Berghout, A. (2011). Islamisation in modern sciences: The way forward. Revelation and Science, 1(3), 21-34.

Berlin, D., \& White, A. (1994). The Berlin-White integrated science and mathematics model. School Science and Mathematics, 94(1), 2-4. https://doi.org/10.1111/j.1949-8594.1994.tb12280.x

Berlin, D., \& White, A. L. (1995). Connecting school science and mathematics. In P. A. House \& A. F. C oxford (Eds.), Connecting mathematics across the curriculum. 1995 National Council of Teachers of Mathematics Yearbook (pp. 22-33). Reston, VA: National Council of Teachers of Mathematics

Berube, M., \& Berube, C. (2007). The End of School Reform. Maryland: Rowman and Littlefield.

Bin Salamah, M. (2001). An investigation of the relationship between Saudi teachers' curriculum perspectives and their preference of curriculum development models. UMI. Ed.D. Dissertation. Morgantown; West Virginia University

Bogdan, R., \& Biklen, S. (1998). Qualitative research in education. Needham Heights, MA: Allyn \& Bacon.

Brannen, J., \& Nilsen, A. (2011). Comparative biographies in case-based cross-national research: methodological considerations. Sociology, 45(4), 603-619. https://doi.org/10.1177/0038038511406602

Brooks, G., \& Brooks, G. (1993). In search of understanding: The case for constructivism classroom. Alexandria, VA: Association for Supervision and Curriculum Development.

Brown, R., Brown, J., Reardon, K., \& Merrill, C. (2011). Understanding STEM: Current perceptions. Technology and Engineering Teacher, 70(6), 5-9.

Bybee, R. (2010). Advancing STEM education: A 2020 vision. Technology and Engineering Teacher, 70(1), 3035.

Bybee, R. (2013). The case for STEM education: Challenges and opportunities. National Science Teachers Association.

Cardella, M. (2014). Engineering in pre-college settings: synthesizing research, policy, and practices. Purdue University Press.

Chang, C., \& Mao, S. (1999). Comparison of Taiwan science students' outcomes with inquiry-group versus traditional instruction. The Journal of Educational Research, 92(6), 340-346. https://doi.org/10.1080/00220679909597617

Clarke, D., \& Hollingsworth, H. (2002). Elaborating a model of teacher professional growth. Teaching and Teacher Education, 18(8), 947-967. https://doi.org/10.1016/S0742-051X(02)00053-7

Claxton, G. (2007). Expanding young people's capacity to learn. British Journal of Educational Studies, 55(2), 1-20. https://doi.org/10.1111/j.1467-8527.2007.00369.x

Coffey, X., Elby, A., Tang, X., \& Levin, D. (2010). The scientific method and scientific inquiry; Tensions in teaching and learning. Science Education, 94(1), 29-42.

Cohen, L., Manion, L., \& Morrison, K. (2013). Research methods in education. Oxford: Routledge. https://doi.org/10.4324/9780203720967

Corlu, S., Capraro, R., \& Capraro, M. (2014). Introducing STEM education: Implementation for educating our teachers for the age of innovation. Education and Science, 39(171), 74-85.

Crabtree, B., \& Miller, W. (1999). Doing qualitative research (2nd ed.). Thousand Oaks, CA: Sage Publications, Inc.

Creswell, J. (2003). Research design: Qualitative, quantitative, and mixed methods approaches. Thousand Oaks, CA: SAGE Publications.

Creswell, J. (2013). Qualitative inquiry \& research design: Choosing among the five approaches. Thousand Oaks, CA: SAGE Publications.

Creswell, J., \& Plano C. (2007). Designing and conducting mixed methods research. Thousand Oaks, CA: 
SAGE Publications. https://doi.org/10.1177/1558689807306132

Crippen, K., \& Archambault, L. (2012). Scaffolded inquiry-based instruction with technology: A signature pedagogy for STEM education. Computers in the Schools, 29(1-2), 157-173. https://doi.org/10.1080/07380569.2012.658733

Cutucache, C., Luhr, J., Nelson, K., Grandgenett, N., \& Tapprich, W. (2016). NE STEM 4U: an out-of-school time academic program to improve achievement of socioeconomically disadvantaged youth in STEM areas. International Journal of STEM Education, 3(1), 1-7. https://doi.org/10.1186/s40594-016-0037-0

Dangor, S. (2005). Islamization of Disciplines: Towards an indigenous educational system. Educational Philosophy and Theory, 37(4), 519-531. https://doi.org/10.1111/j.1469-5812.2005.00138.x

Darling-Hammond, L. (2000). Teacher quality and student achievement. Education Policy Analysis Archives, 8 , 1. https://doi.org/10.14507/epaa.v8n1.2000

Darling-Hammond, L. (2000a). How teacher education matters. Journal of Teacher Education, 51(3), 166-173. https://doi.org/10.1177/0022487100051003002

DeCoito, I. (2015). Focusing on science, technology, engineering, and mathematics (STEM) initiatives in K-12 education. Ontario: Social Sciences and Humanities Research Council of Canada.

Dede, C., Ketelhut, D., \& Nelson, B. (2004). Design-based research on gender, class, race, and ethnicity in a multi-user virtual environment (vol. 2807). In American educational Research Association Conference, San Diego, CA, Retrieved.

Deslauriers, L., Schelew, E., \& Wieman, C. (2011). Improved learning in a large-enrollment physics class. Science, 332(6031), 862-864. https://doi.org/10.1126/science.1201783

De Vaus, D. (2002). Surveys in social research (5th ed.). Oxford: Psychology Press. https://doi.org/10.4135/9781446263495

DiCicco-Bloom, B., \& Crabtree, B. (2006). The qualitative research interview. Medical Education, 40(4), 314321. https://doi.org/10.1111/j.1365-2929.2006.02418.x

Dierdorp, A., Bakker, A., van Maanen, J., \& Eijkelhof, H. (2014). Meaningful statistics in professional practices as a bridge between mathematics and science: an evaluation of a design research project. International Journal of STEM Education, 1(1), 1-15. https://doi.org/10.1186/s40594-014-0009-1

Dodeen, H., Abdelfattah, F., Shumrani, S., \& Abu Hilal, M. (2012). The effects of teachers' qualifications, practices, and perceptions on student achievement in TIMSS mathematics: A comparison of two countries. International Journal of Testing, 12(1), 61-77. https://doi.org/10.1080/15305058.2011.621568

Driscoll, D., Appiah-Yeboah, A., Salib, P., \& Rupert, D. (2007). Merging qualitative and quantitative data in mixed methods research: How to and why not. Ecological and Environmental Anthropology, 3(1), 19-28.

Dugger, W. (2010). Evolution of STEM in the United States. In the 6th Biennial International Conference on Technology Education Research, Surfers Paradise, Queensland, Australia.

Ebert-May, D., Derting, T., Hodder, J., Momsen, J., Long, T., \& Jardeleza, S. (2011). What we say is not what we do: effective evaluation of faculty professional development programs. BioScience, 61(7), 550-558. https://doi.org/10.1525/bio.2011.61.7.9

Elbaz, F. (2004). Reform in Arab countries: the role of education. Journal of education, 30(2), 245-264. https://doi.org/10.1080/13674580100200244

El-Deghaidy, H., \& Mansour, N. (2015). Science Teachers' perceptions of STEM education: Possibilities and challenges. International Journal of Learning and Teaching, 1(1), 51-54. https://doi.org/10.18178/ijlt.1.1.51-54

Elliott, J. (2005). Using narrative in social research: Qualitative and quantitative approaches. Thousand Oaks, CA: Sage Publications, Inc. https://doi.org/10.4135/9780857020246

El-Sanabary, N. (1994). Female education in Saudi Arabia and the reproduction of gender division. Gender and Education, 6(2), 141-150. https://doi.org/10.1080/0954025940060204

El Sayary, A., Forawi, S., \& Mansour, N. (2015). STEM education and problem-based learning. The Routledge international handbook of research on teaching thinking, 357.

English, L. (2016). STEM education K-12: perspectives on integration. International Journal of STEM 
Education, 3(3), 1-8. https://doi.org/10.1186/s40594-016-0036-1

English, L., \& King, D. (2015). STEM learning through engineering design: fourth-grade students' investigations in aerospace. International Journal of STEM Education, 2(1), 1-18. https://doi.org/10.1186/s40594-015-0027-7

Erickson, F. (2012). Qualitative research methods for science education. Second international handbook of science education, 1451-1469. Dordrecht: Springer. https://doi.org/10.1007/978-1-4020-9041-7_93

Ertmer, P., Ottenbreit-Leftwich, A., Sadik, O., Sendurur, E., \& Sendurur, P. (2012). Teacher beliefs and technology integration practices: A critical relationship. Computers \& Education, 59(2), 423-435. https://doi.org/10.1016/j.compedu.2012.02.001

Evagorou, M., Erduran, S., \& Mäntylä, T. (2015). The role of visual representations in scientific practices: from conceptual understanding and knowledge generation to 'seeing' how science works. International Journal of STEM Education, 2(1), 1-13. https://doi.org/10.1186/s40594-015-0024-x

Fairweather, J. (2008). Linking evidence and promising practices in science, technology, engineering, and mathematics (STEM) undergraduate education. Board of Science Education, National Research Council, The National Academies, Washington, DC.

Ferguson, R. (1991). Paying for public education: New evidence on how and why money matters. Harvard Journal on Legislation, 44(1), 55-63.

Figliano, F. (2007). Strategies for Integrating STEM Content: A pilot case study. Ph.D. Thesis, Virginia Tech.

Forawi, S. (2015). Science Teacher Professional Development Needs in the United Arab Emirates, In N. Mansour \& S. Al-Shamrani (Eds). Science Education in the Arab Gulf States: Visions, Sociocultural Contexts and Challenges (pp. 25-32). Rotterdam: Sense Publishers. https://doi.org/10.1007/978-94-6300-049-9_3

Fraenkel, J., \& Wallen, N. (1993). How to design and evaluate research in education (vol. 7). New York: McGraw-Hill.

Fraenkel, J., Wallen, N., \& Hyun, H. (2015). How to design and evaluate research in education (9th ed.). New York: McGraw-Hill education.

Froyd, J. (2008). White paper on promising practices in undergraduate STEM education. Commissioned paper for the Evidence on Promising Practices in Undergraduate Science, Technology, Engineering, and Mathematics (STEM) Education Project, The National Academies Board on Science Education.

Frykholm, J., \& Glasson, G. (2005). Connecting science and mathematics instruction: Pedagogical context knowledge for teachers. School Science and Mathematics, 105(3), 127-141. https://doi.org/10.1111/j.1949-8594.2005.tb18047.x

Gall, M. (1970). The use of questions in teaching. Review of Educational Research, 40(5), 707-721. https://doi.org/10.3102/00346543040005707

Gao, X., \& Schwartz, B. (2015). Classroom implementation of active instructional strategies for undergraduate STEM education. International Journal of Information and Education Technology, 5(9), 688-692. https://doi.org/10.7763/IJIET.2015.V5.593

Gentry, A. (2016). An integrated mathematics/science activity for secondary students: Development, implementation, and student feedback. Ed.D. Dissertation. Colorado State University.

Glesne, C. (2011). Becoming qualitative researchers. Boston: Pearson Education.

Goe, L. (2007). The link between teacher quality and student outcomes: A research synthesis. National Comprehensive Center for Teacher Quality.

Goe, L., \& Stickler, L. (2008). Teacher quality and student achievement: Making the most of recent research. National Comprehensive Center for Teacher Quality.

Greenwald, R., Hedges, L., \& Laine, D. (1996). The effect of school resources on student achievement. Review of Educational Research, 66(3), 361-396. https://doi.org/10.3102/00346543066003361

Hall, C., Dickerson, J., Batts, D., Kauffmann, P., \& Bosse, M. (2011). Are we missing opportunities to encourage interest in STEM Fields? Journal of Technology Education, 23(1), 32-46. https://doi.org/10.21061/jte.v23i1.a.4 
Hammer, G., du Prel, J., \& Blettner, M. (2009). Avoiding bias in observational studies: Part 8 in a series of articles on evaluation of scientific publications. Deutsches Ärzteblatt International, 106(41), 664-668. https://doi.org/10.3238/arztebl.2009.0664

Haneef, A. (2005). A critical survey of Islamization of knowledge. Kuala Lumpur: International Islamic University Malaysia.

Hanson, W., Creswell, J., Clark, V., Petska, K., \& Creswell, D. (2005). Mixed methods research designs in counseling psychology. Journal of Counseling Psychology, 52(2), 224-235. https://doi.org/10.1037/0022-0167.52.2.224

Han, S., Yalvac, B., Capraro, M., \& Capraro, R. (2015). In-service teachers' implementation and understanding of STEM project based learning. Eurasia Journal of Mathematics, Science \& Technology Education, 11(1), $63-76$.

Hartzler, D. (2000). A meta-analysis of studies conducted on integrated curriculum programs and their effects on student achievement. Ed.D. Dissertation, [SI:sn].

Henderson, C., Cole, R., Froyd, J., \& Khatri, R. (2012). Five claims about effective propagation (pp. 30-31). A White Paper prepared for January.

Henderson, C., \& Dancy, M. (2007). Barriers to the use of research-based instructional strategies: The influence of both individual and situational characteristics. Physical Review Special Topics-Physics Education Research, 3(2), 020-102. https://doi.org/10.1103/PhysRevSTPER.3.020102

Henderson, C., \& Dancy, M. (2011). Increasing the impact and diffusion of STEM education innovations. In Invited paper for the National Academy of Engineering, Center for the Advancement of Engineering Education Forum, Impact and Diffusion of Transformative Engineering Education Innovations. Retrieved from http://www.nae.edu/File.aspx.

Herschbach, D. (2011). The STEM initiative: Constraints and challenges. Journal of STEM Teacher Education, 48(1), 96-122. https://doi.org/10.30707/JSTE48.1Herschbach

Hofstein, A., Eilks, I., \& Bybee, R. (2011). Societal issues and their importance for contemporary science education-A pedagogical justification and the state-of-the-art in Israel, Germany, and the USA. International Journal of Science and Mathematics Education, 9(6), 1459-1483. https://doi.org/10.1007/s10763-010-9273-9

Honey, M., Pearson, G., \& Schweingruber, H. (eds.) (2014). STEM integration in K-12 education: Status, prospects, and an agenda for research. Washington, D.C.: National Academies Press.

Hopkins, K. (1998). Educational and psychological measurement and evaluation. Boston: Allyn \& Bacon.

Hora, M. (2012). Organizational factors and instructional decision-making: A cognitive perspective. The Review of Higher Education, 35(2), 207-235. https://doi.org/10.1353/rhe.2012.0001

Hurley, M. (2001). Reviewing integrated science and mathematics: The search for evidence and definitions from new perspectives. School Science and Mathematics, 101(5), 259-268. https://doi.org/10.1111/j.1949-8594.2001.tb18028.x

International Association for the Evaluation of Educational Achievement. (2011). Trends in international mathematics and science study (TIMSS). Amsterdam: The International Association for the Evaluation of Educational Achievement.

Ivankova, N., Creswell, J., \& Stick, S. (2006). Using mixed-methods sequential explanatory design: From theory to practice. Field Methods, 18(1), 3-20. https://doi.org/10.1177/1525822X05282260

Johnson, B., \& Onwuegbuzie, A. (2004). Mixed methods research: A research paradigm who's time has come. Educational Researcher, 33(7), 14-26. https://doi.org/10.3102/0013189X033007014

Johnson, B., Onwuegbuzie, A., \& Turner, L. (2007). Toward a definition of mixed methods research. Journal of Mixed Methods Research, 1(2), 112-133. https://doi.org/10.1177/1558689806298224

Johnson, C. (2013). Conceptualizing integrated STEM education. School Science \& Mathematics, 113(8), 367368. https://doi.org/10.1111/ssm.12043

Johns, R. (2005). One size doesn't fit all: Selecting response scales for attitude items. Journal of Elections, Public Opinion \& Parties, 15(2), 237-264. https://doi.org/10.1080/13689880500178849

Kapborg, I., \& Bertero, C. (2002). Using an interpreter in qualitative interviews: Does it threaten validity? 
Nursing Inquiry, 9(1), 52-56. https://doi.org/10.1046/j.1440-1800.2002.00127.x

Kelley, T., \& Knowles, J., (2016). A conceptual framework for integrated STEM education. International Journal of STEM Education, 3(1), 1-11. https://doi.org/10.1186/s40594-016-0046-z

Kennedy, T., \& Odell, M. (2014). Engaging students in STEM education. Science Education International, 25(3), 246-258.

Kilaha, K. (2010). Tecahers' Characteristics and Their Effects on Students' Acheivements in Chemistry: A Case Study of Bungoma North District. Ed.D. Dissertation. Moi University.

King, K., \& Wiseman, D. (2001). Comparing science efficacy beliefs of elementary education majors in integrated and non-integrated teacher education coursework. Journal of Science Teacher Education, 12(2), 143-153. https://doi.org/10.1023/A:1016681823643

Kingdom of Saudi Arabia Ministry of Education. (2013). Summary Statistics on General Education In K.S.A: Summary Statistics on Male \& Female Education by Stage \& Type of Educationfor Academic Year. National Center for Education Information

Kiray, A. (2012). A new model for the integration of science and mathematics: The balance model. Energy Education Science and Technology (Part B: Social and Educational Studies), 4(3), 1181-1196.

Klassen, R., \& Chiu, M. (2010). Effects on teachers' self-efficacy and job satisfaction: Teacher gender, years of experience, and job stress. Journal of Educational Psychology, 102(3), 741. https://doi.org/10.1037/a0019237

Knezek, G., Christensen, R., Tyler-wood, T., \& Periathiruvadi, S. (2013). Impact of environmental power monitoring activities on middle school student perceptions of STEM. Science Education International, 24(1), 98-123.

Komoroske, L., Hameed, S., Szoboszlai, A., Newsom, A., \& Williams, S. (2015). A scientist's guide to achieving broader impacts through K-12 STEM collaboration. BioScience, 65(3), 313-322. https://doi.org/10.1093/biosci/biu222

Kotrlik, J., \& Higgins, C. (2001). Organizational research: Determining appropriate sample size in survey research appropriate sample size in survey research. Information Technology, Learning, and Performance Journal, 19(1), 43-50.

Kuder, G., \& Richardson, M. (1937). The theory of the estimation of test reliability. Psychometrika, 2(3), 151160. https://doi.org/10.1007/BF02288391

Kvale, S., \& Brinkmann, S. (2009). Inter Views: Learning the Craft of Qualitative Research Interviewing. Thousands Oak, CA., SAGE Publications.

LaForce, M., Noble, E., King, H., Century, J., Blackwell, C., Holt, S., Ibrahim, A., \& Loo, S. (2016). The eight essential elements of inclusive STEM high schools. International Journal of STEM Education, 3(1), 1-11. https://doi.org/10.1186/s40594-016-0054-z

Lancaster, G., Dodd, S., \& Williamson, P. (2004). Design and analysis of pilot studies: recommendations for good practice. Journal of Evaluation in Clinical Practice, 10(2), 307-412. https://doi.org/10.1111/j..2002.384.doc.x

Lantz Jr, H. (2009). Science, technology, engineering, and mathematics (STEM) education what form? What function? Report, Currtech Integrations, Baltimore.

Lebeaume, J. (2011). Integration of science, technology, engineering and mathematics: Is this curricular revolution really possible in France? Design and Technology Education, 16(1), 47-52.

Levitt, K. (2002). An analysis of elementary teachers' beliefs regarding the teaching and learning of science, Science Education, 86(1), 1-22. https://doi.org/10.1002/sce.1042

Lin, H., Gorrell, J., \& Taylor, J. (2002). Influence of culture and education on US and Taiwan pre service teachers' efficacy beliefs. The Journal of Educational Research, 96(1), 37-46. https://doi.org/10.1080/00220670209598789

Lincoln, Y., Lynham, S., \& Guba, E. (2011). Paradigmatic controversies, contradictions, and emerging confluences, revisited. The Sage Handbook of Qualitative Research, 4, 97-128.

Lozano, L., García-Cueto, E., \& Muñiz, J. (2008). Effect of the number of response categories on the reliability and validity of rating scales. Methodology, 4(2), 73-79. https://doi.org/10.1027/1614-2241.4.2.73 
Luft, J., \& Roehrig, G. (2007). Capturing science teachers' epistemological beliefs: The development of the teacher beliefs interview. Electronic Journal of Science Education, 11(2), 38-63.

Lund, T., \& Stains, M. (2015). The importance of context: an exploration of factors influencing the adoption of student-centered teaching among chemistry, biology, and physics faculty. International Journal of STEM Education, 2(1), 1-21. https://doi.org/10.1186/s40594-015-0026-8

Ma, V., \& Ma, X. (2014). A comparative analysis of the relationship between learning styles and mathematics performance. International Journal of STEM Education, 1(1), 1-13. https://doi.org/10.1186/2196-7822-1-3

Mackenzie, N., \& Knipe, S. (2006). Research dilemmas: Paradigms, methods and methodology. Issues in Educational Research, 16(2), 193-205.

Maroun, N., Samman, H., Moujaes, C.N., Abouchakra, R., \& Insight, I. (2008). How to succeed at education reform: The case for Saudi Arabia and the broader GCC region (pp. 109-113). Abu Dhabi, Ideation Center, Booz and Company.

Marshall, J., Horton, R., Igo, B., \& Switzer, D. (2009). K-12 science and mathematics teachers' beliefs about and use of inquiry in the classroom. International Journal of Science and Mathematics Education, 7(3), 575596. https://doi.org/10.1007/s10763-007-9122-7

Mataric, M., Koenig, N., \& Feil-Seifer, D. (2007). Materials for Enabling Hands-On Robotics and STEM Education (pp. 99-102). The AAAI spring symposium: Semantic scientific knowledge integration.

McConnell, T., Parker, J., \& Eberhardt, J. (2013). Assessing teachers' science content knowledge: A strategy for assessing depth of understanding. Journal of Science Teacher Education, 24(4), 717-743. https://doi.org/10.1007/s10972-013-9342-3

McMillan, J. (2004). Educational research: Fundamentals for the consumer (4th ed.). London: Pearson Education, Inc.

Melles, G. (2005). Beyond the romantic impulse for authentic data to co construction of meaning in interview-based educational research. Qualitative Research Journal, 5(2), 21.

Merriam, B. (2009). Qualitative research: A guide to design and implementation (2nd ed.). California: Jossey-Bass.

Michael, J. (2006). Where's the evidence that active learning works? Advances in Physiology Education, 30(4), 159-167. https://doi.org/10.1152/advan.00053.2006

Mihelich, J., Sarathchandra, D., Hormel, L., Storrs, D., \& Wiest, M. (2017). Public understanding of science and K-12 STEM education outcomes: Effects of Idaho parents' orientation toward science on students' attitudes toward science. Bulletin of Science, Technology \& Society. https://doi.org/10.1177/0270467616687217

Miller, V. (2015). Value of humanistic grounds in the field of legal education of youth. Procardia-Social and Behavioral Sciences, 166, 427-433. https://doi.org/10.1016/j.sbspro.2014.12.548

Ministry of Education. (2008). National report on education development in the Kingdom of Saudi Arabia. Riyadh: Ministry of Education.

Moore, T., Stohlmann, M., Wang, H., Tank, K., Glancy, A., \& Roehrig, G. (2014). Implementation and integration of engineering in K-12 STEM education. In S. Purzer, J. Strobel \& M. Cardella (Eds.), Engineering in Pre-College Settings: Synthesizing Research, Policy, and Practices (pp. 35-60). West Lafayette: Purdue University Press. https://doi.org/10.2307/j.ctt6wq7bh.7

Motschnig-Pitrik, R., \& Holzinger, A. (2002). Student-centered teaching meets new media: Concept and case study. Educational Technology \& Society, 5(4), 160-172.

Muijs, D. (2011). Doing Quantitative Research in Education with SPSS (2nd ed.). Thousand Oaks, CA: Sage Publications. https://doi.org/10.4135/9781849203241

Mullis, I., Martin, M., \& Foy, P. (2009). Findings from IEA's Trends in International Mathematics and Science Study at the Fourth and Eighth Grades (Re- vised). TIMSS 2007 international mathematics report. Chestnut Hill, MA: TIMSS \& PIRLS International Study Center, Boston College.

Mullis, I., Martin, M., Goh, S., \& Cotter, K. (2016). TIMSS 2015 Encyclopedia: Education Policy and Curriculum in Mathematics and Science. Boston College, TIMSS \& PIRLS International Study Center. Retrieved from http://timssandpirls.bc.edu/timss2015/encyclopedia/

Mullis, I., Martin, M., Gonzalez, E., \& Chrostowski, J. (2004). Findings from IEA's Trends in International 
Mathematics and Science Study at the Fourth and Eighth Grades. TIMSS 2003 International Science Report. TIMSS \& PIRLS International Study Center. Boston College.

Mulnix, A., \& Vandegrift, E. (2014). A tipping point in STEM education reform. Journal of College Science Teaching, 43(3), 14-16.

Nadelson, S. (2009). How true inquiry can happen in K-16 science education. The Science Educator, 18(1), 4857.

National Academy of Engineering and National Research Council. (2009). Engineering in K-12 education understanding the status and improving the prospects. Washington, D.C.: The National Academies Press.

National Commission on Mathematics and Science Teaching for the 21st Century (US) and United States. Dept. of Education. (2000). Before it is too late: A report to the nation from the national commission on mathematics and science teaching for the 21st century. Washington, D.C.: Diane Publishing Company.

National Research Council. (2012). Discipline-based education research: understanding and improving learning in undergraduate science and engineering (Vol. 2012). Washington, D.C: The National Academies Press.

NGSS Lead States. (2013). Next generation science standards: For states, by states. Washington, DC: National Academies Press.

Nuangchalerm, P. (2010). Engaging students to perceive nature of science through socioscientific issues-based instruction. Online Submission, 13(1), 34-37.

Nye, B., Konstantopoulos, S., \& Hedges, L. (2004). How large are teacher effects? Educational Evaluation and Policy Analysis, 26(3), 237-257. https://doi.org/10.3102/01623737026003237

Obeikan Education. (2012). General information. Retrieved from $\mathrm{http} / / / \mathrm{www}$. obeikaneducation.com/en/content/k-12-education

Obeikan for Research and Development. (2010). Project of mathematics and natural sciences. Retrieved January 28, 2012, from http://msd-ord.com/project.htm

Onwuegbuzie, A., \& Leech, N. (2004). Enhancing the interpretation of "significant" findings: The role of mixed methods research. The Qualitative Report, 9(4), 770-792.

Owolabi, O., \& Adebayo, J. (2012). Effect of teacher's qualification on the performance of senior secondary school physics students: Implication on technology in Nigeria. English Language Teaching, 5(6), 72-77. https://doi.org/10.5539/elt.v5n6p72

Oxford Business Group. (2015). Saudi Arabia expands educational offerings at all levels. Oxford: oxford Business Group.

Oyaid, A. (2009). Education policy in Saudi Arabia and its relation to secondary school teachers' ICT Use, perceptions, and views of the future of ICT in education. Ed.D. Dissertation, University of Exeter.

Parsons, J., \& Taylor, L. (2011). Improving student engagement. Current Issues in Education, 14(1), 1-33.

Patton, M. (2002). Qualitative research and Evaluation Methods (3rd ed.). Thousand Oaks, CA: SAGE Publications.

Paul, R. (1995). Critical thinking: How to prepare students for a rapidly changing world. Santa Rosa, CA: Foundation for Critical Thinking.

Pawson, C. (2012). A comparative analysis of students' satisfaction with teaching on STEM vs. non-STEM programs. Psychology Teaching Review, 18(2), 16-21.

Pelch, M., \& McConnell, D. (2016). Challenging instructors to change: a mixed methods investigation on the effects of material development on the pedagogical beliefs of geoscience instructors. International Journal of STEM Education, 3(1), 1-18. https://doi.org/10.1186/s40594-016-0039-y

Penuel, W., Fishman, B., Yamaguchi, R., \& Gallagher, L. (2007). What makes professional development effective? Strategies that foster curriculum implementation. American Educational Research Journal, 44(4), 921-958. https://doi.org/10.3102/0002831207308221

Prince, M., \& Felder, R. (2006). Inductive teaching and learning methods: Definitions, comparisons, and research bases. Journal of Engineering Education, 95(2), 123-138. https://doi.org/10.1002/j.2168-9830.2006.tb00884.x

Pritchard, J. (2016). STEM education for high-ability learners. Science Scope, 39(9), 86-88. 
Prokop, M. (2003). Saudi Arabia: The politics of education. International Affairs, 79(1), 77-89. https://doi.org/10.1111/1468-2346.00296

Pitt, J. (2009). Blurring the boundaries - STEM education and education for sustainable development. Design and Technology Education: An International Journal, 14(1), 37-48.

Qu, S., \& Dumay, J. (2011). The qualitative research interview. Qualitative Research in Accounting \& Management, 8(3), 238-264. https://doi.org/10.1108/11766091111162070

Rattray, J., \& Jones, M. (2007). Essential elements of questionnaire design and development. Journal of Clinical Nursing, 16(2), 234-243. https://doi.org/10.1111/j.1365-2702.2006.01573.x

Rea, L., \& Parker, R. (2012). Designing and conducting survey research: A comprehensive guide. New York: John Wiley \& Sons.

Rehman, J. (2003). Searching for scientific facts in the Qur'an: Islamization of knowledge or a new form of scientism? Islam \& Science, 1(2), 245.

Roberta, N. (2015). Promoting innovative thinking. American Journal of Public Health, 105(1), 114-118. https://doi.org/10.2105/AJPH.2014.302365

Rodger, B. (2010). Advancing STEM education: A 2020 vision. Technology and Engineering Teacher, 70(1), $30-35$.

Rogers, E. (2003). Diffusion of innovations (5th ed.). New York: Free Press.

Rozenszajn, R., \& Yarden, A. (2014). Expansion of biology teachers' pedagogical content knowledge (PCK) during a long-term professional development program. Research in Science Education, 44(1), 189-213. https://doi.org/10.1007/s11165-013-9378-6

Rule, P., \& John, V. (2011). Your guide to case study research. Pretoria: Van Schaik.

Sadler, T. (2004). Informal reasoning regarding socio scientific issues: A critical review of research. Journal of Research in Science Teaching, 41(5), 513-536. https://doi.org/10.1002/tea.20009

Sadler, T., Barab, S., \& Scott, B. (2007). What do students gain by engaging in socio scientific inquiry? Research in Science Education, 37(4), 371-391. https://doi.org/10.1007/s11165-006-9030-9

Sadlo, G., \& Richardson, J. (2003). Approaches to studying and perceptions of the academic environment in students following problem-based and subject-based curricula. Higher Education Research \& Development, 22(3), 253-274. https://doi.org/10.1080/0729436032000145130

Sandelowski, M. (2000). Focus on research methods combining qualitative and quantitative sampling, data collection, and analysis techniques in mixed-method Studies. Research in Nursing \& Health, 23, 246-255. https://doi.org/10.1002/1098-240X(200006)23:3<246::AID-NUR9>3.0.CO;2-H

Sanders, M. (2009). STEM, STEM education, STEM mania. The Technology Teacher, 68(4), 20-26.

Savery, J. (2015). Essential readings in problem-based learning. Washington DC: Purdue University Press.

Schwartz, M., Sadler, P., Sonnert, G., \& Tai, R. (2009). Depth versus breadth: How content coverage in high school science courses relates to later success in college science coursework. Science Education, 93(5), 798-826. https://doi.org/10.1002/sce.20328

Sedgwick, R. (2001). Education in Saudi Arabia. World education news and reviews. Retrieved from $\mathrm{http} / / /$ wenr.wes.org/2001/11/wenr-nov-dec-2001-education-in-saudi-arabia

Seidman, I. (2013). Interviewing as qualitative research: A guide for researchers in education and the social sciences. New York: Teachers college press.

Sharp, L., McDonald, A., Sim, P., Knamiller, C., Sefton, C., \& Wong, S. (2011). Positivism, post-positivism and domestic water demand: Interrelating science across the paradigmatic divide. Transactions of the Institute of British Geographers, 36(4), 501-515. https://doi.org/10.1111/j.1475-5661.2011.00435.x

Simon, M. (2011). Dissertation and scholarly research: Recipes for success (2011 ed.). Seattle, WA: Dissertation Success, LLC.

Slavit, D., Nelson, T., \& Lesseig, K. (2016). The teachers' role in developing, opening, and nurturing an inclusive STEM-focused school. International Journal of STEM Education, 3(1), 1-17. https://doi.org/10.1186/s40594-016-0040-5

Smith, M., Jones, F., Gilbert, S., \& Wieman, C. (2013). The classroom observation protocol for undergraduate 
STEM (COPUS): A new instrument to characterize university STEM classroom practices. CBE Life Sciences Education, 12(4), 618-627. https://doi.org/10.1187/cbe.13-08-0154

Stake, R. (2013). Multiple case study analysis. New York: Guilford Press.

Stalinsky, S. (2002). Preliminary Overview-Saudi Arabia's education system: Curriculum, spreading Saudi education to the world and the official Saudi position on education Policy. Washington DC: The Middle East Media Research Centre.

Stallings, M. (1998). Building a professional support program for the beginningTeacher. Ed.D Dissertation. Virginia Polytechnic Institute and State University.

Stanford, C., Cole, R., Froyd, J., Friedrichsen, D., Khatri, R., \& Henderson, C. (2016). Supporting sustained adoption of education innovations: The designing for sustained adoption assessment instrument. International Journal of STEM Education, 3(1), 1-13. https://doi.org/10.1186/s40594-016-0034-3

STEM Task Force Report. (2014). Innovate: A blueprint for science, technology, engineering, and mathematics in California public education. California: Californians Dedicated to Education Foundation.

Stinson, K., Harkness, S., Meyer, H., \& Stallworth, J. (2009). Mathematics and science integration: Models and characterizations. School Science and Mathematics, 109(3), 153-161. https://doi.org/10.1111/j.1949-8594.2009.tb17951.x

Stohlmann, M., Moore, T., \& Roehrig, G. (2012). Considerations for teaching Integrated STEM education. Journal of Pre-College Engineering Education Research, 2(1), 27-34. https://doi.org/10.5703/1288284314653

Tatar, M., \& Horenczyk, G. (2003). Diversity-related burnout among teachers. Teaching and Teacher Education, 19(4), 397-408. https://doi.org/10.1016/S0742-051X(03)00024-6

Tavakol, M., \& Dennick, R. (2011). Making sense of Cronbach's alpha. International Journal of Medical Education, 2, 53. https://doi.org/10.5116/ijme.4dfb.8dfd

Teddlie, C., \& Tashakkori, A. (2009). Foundations of mixed methods research: Integrating quantitative and qualitative approaches in the social and behavioral Sciences. Thousand Oaks, CA: Sage Publications.

Tilak, J. (1992). Education and structural adjustments. Prospects, 84(4), 407-422. https://doi.org/10.1007/BF02195685

Tofl-Grehl, C., \& Callahan, C. (2016). STEM school discourse patterns. Journal of STEM Education: Innovations and Research, 17(2), 34-41.

Trueman, R. (2013). Productive failure in STEM education. Journal of Educational Technology Systems, 42(3), 199-214. https://doi.org/10.2190/ET.42.3.b

Trygstad, P., Smith, P., Banilower, E., \& Nelson, M. (2013). The status of elementary science education: Are we ready for the next generation science standards? North Carolina: Horizon Research, Inc.

Tsang, K. (2012). The use of midpoint on Likert Scale: The implications for educational research. Hong Kong Teachers' Centre Journal, 11, 121-130.

Tuckman, B., \& Harper, B. (2012). Conducting educational research. Maryland: Rowman \& Littlefield Publishers.

Turner, D. (2010). Qualitative interview design: A practical guide for novice investigators. The Qualitative Report, 15(3), 754-760.

Tyler, R. (2013). Basic principles of curriculum and instruction. Chicago, IL: University of Chicago Press. https://doi.org/10.7208/chicago/9780226086644.001.0001

Tytler, R. (2007). Re-imagining science education: Engaging students in science for Australia's future. Melbourne: Australian Council for Educational Research. https://doi.org/10.1007/s11165-006-9028-3

Ugbe, A. (2000). Influence of teacher's competence on student's academic performance in senior secondary school chemistry. Educational Journal, 8, 61-69.

UNESCO. (2010). Annual Report, UNESCO Office Jakarta. Retrieved from http://unesdoc.unesco.org/images/0019/001921/192108e.pdf

Van Teijlingen, E., \& Hundley, V. (2002). The importance of pilot studies. Nursing Standard, 16(40), 33-36. https://doi.org/10.7748/ns2002.06.16.40.33.c3214 
Vasquez, J., Sneider, C., \& Comer, M. (2013). STEM lesson essentials, grades 3-8: integrating science, technology, engineering, and mathematics. Portsmouth, NH: Heinemann

Wallace, M., \& Webb, A. (2016). In the midst of a shift: Undergraduate STEM education and "PBL" enactment. Journal of College Science Teaching, 46(2), 47-55. https://doi.org/10.2505/4/jcst16_046_02_47

Wang, H., Moore, T., Roehrig, G., \& Park, M. (2011). STEM integration: Teacher perceptions and practice. Journal of Pre-College Engineering Education Research, 1(2), 1-14.

Weis, L., Eisenhart, M., Cipollone, K., Stich, A., Nikischer, A., Hanson, J., Ohle Leibrandt, S., Allen, C., \& Dominguez, R. (2015). In the guise of STEM education reform: Opportunity structures and outcomes in inclusive STEM-focused high schools. American Educational Research Journal, 52(6), 1024-1059. https://doi.org/10.3102/0002831215604045

Wenglinsky, H. (2002). How schools matter: The link between teacher classroom practices and student academic performance. Education Policy Analysis Archives, 10(12). https://doi.org/10.14507/epaa.v10n12.2002

Williams, C., Walter, E., Henderson, C., \& Beach, A. (2015). Describing undergraduate STEM teaching practices: a comparison of instructor self-report instruments. International Journal of STEM Education, 2(1), 1-14. https://doi.org/10.1186/s40594-015-0031-y

Williams, J. (2011). STEM Education: Proceed with caution. Design and Technology Education: An International Journal, 16(1), 26-35.

Willms, J., Friesen, S., \& Milton, P. (2009). What did you do in school today? Transforming classrooms through social, academic, and intellectual engagement (First National Report). Ontario: Canadian Education Association.

Windschitl, M. (2003). Inquiry projects in science teacher education: What can investigative experiences reveal about teacher thinking and eventual classroom practice? Science Education, 87(1), 112-143. https://doi.org/10.1002/sce.10044

Wolters, C., \& Daugherty, S. (2007). Goal structures and teachers' sense of efficacy: Their relation and association to teaching experience and academic level. Journal of Educational Psychology, 99, 181-193. https://doi.org/10.1037/0022-0663.99.1.181

Wragg, T. (2013). An introduction to classroom observation. London: Routledge. https://doi.org/10.4324/9780203357279

Yala, P., \& Wanjohi, W. (2011). Performance determinants of KCSE in mathematics in secondary schools in Nyamira Division, Kenya. Asian Social Science, 7(20), 107-112. https://doi.org/10.5539/ass.v7n2p107

Yin, K. (2003). Case study research: Design and Methods (3rd ed.). Thousand Oaks, CA: SAGE Publications.

Zaidi, A. H. (2006). Muslim reconstructions of knowledge and the re-enchantment of modernity. Theory Culture and Society, 23(5). 69. https://doi.org/10.1177/0263276406067099

Zeidler, D. (2016). STEM education: A deficit framework for the twenty first century? A sociocultural socio scientific response. Cultural Studies of Science Education, 11(1), 11. https://doi.org/10.1007/s11422-014-9578-z

Zeidler, D., \& Nichols, H. (2009). Socio-scientific issues: Theory and practice. Journal of Elementary Science Education, 21(2), 49-58. https://doi.org/10.1007/BF03173684

Zeidler, L., Sadler, D., Simmons, L., \& Howes, V. (2005). Beyond STS: A research-based framework for socio-scientific issues education. Science Education, 89(3), 357-377. https://doi.org/10.1002/sce.20048

\section{Appendix A}

Teachers' Perceptions of the New Mathematics and Science Curriculum: As a Step Towards STEM Implementation in Saudi Arabia

Teachers Questionnaire (Back translation of Arabic questionnaire to English)

This questionnaire will be used a part of a doctoral thesis to investigate teachers' perception regarding the newly implemented math and science curriculum as a form of STEM education in Saudi, the answers you provide will be used as research data and analyzed for the purpose of the research understudy. Your cooperation in 
completing this questionnaire is greatly appreciated. If you have any questions or emphasis regarding the research or the questionnaire, please contact the researcher: Rehafmadani@hotmail.com.

\section{A. Demographic Information}

1) Gender

2) Years of teaching experience

3) Nationality

4) Qualification

5) Subject taught

\section{B. Teacher Background}

Please indicate how well you are prepared to teach the newly integrated math and science curriculum by choosing the correct answer for the following statements:

\begin{tabular}{|c|c|c|c|}
\hline Statement & Not prepared & Somewhat prepared & Very well prepared \\
\hline \multicolumn{4}{|l|}{ 6) Develop students conceptual understanding of taught subject } \\
\hline \multicolumn{4}{|l|}{ 7) Provide deeper coverage of fewer science/math concepts } \\
\hline \multicolumn{4}{|l|}{ 8) Make connection between science/ math with other subjects } \\
\hline \multicolumn{4}{|l|}{ 9) Lead a class of students using investigative strategies } \\
\hline \multicolumn{4}{|l|}{ 10) Encourage students' interest in math/ science } \\
\hline \multicolumn{4}{|l|}{$\begin{array}{l}\text { 11) Use assigned textbook as a source rather than a primary instructional } \\
\text { tool }\end{array}$} \\
\hline \multicolumn{4}{|l|}{ 12) Connecting taught subjects with students' daily life issues } \\
\hline \multicolumn{4}{|l|}{ 13) Manage a class of students engaged in hands on/project-based activities } \\
\hline \multicolumn{4}{|l|}{ 14) Teaching the newly integrated Math/Science curriculum } \\
\hline \multicolumn{4}{|l|}{ 15) How prepared are you in teaching lessons that appropriately combine } \\
\hline \multicolumn{4}{|l|}{ STEM subjects } \\
\hline \multicolumn{4}{|l|}{ 16) Apply new student-centered teaching techniques } \\
\hline \multicolumn{4}{|l|}{$\begin{array}{l}\text { 17) Using teaching approaches that focuses on improving students critical } \\
\text { thinking and problem solving }\end{array}$} \\
\hline 18) Making connections between different STEM subjects when teaching & & & \\
\hline
\end{tabular}

\section{Teachers' Perception}

As a teacher please provide your opinion on each of the following statements regarding the emphasis of the newly integrated math and science curriculum on students learning outcomes:

\begin{tabular}{|c|c|c|c|c|}
\hline Statement & None & Minimal Emphasis & Moderate Emphasis & Heavy Emphasis \\
\hline \multicolumn{5}{|l|}{ 19) Students interest in math/science subjects } \\
\hline \multicolumn{5}{|l|}{ 20) Aid in learning basic concepts in math/science subjects } \\
\hline \multicolumn{5}{|l|}{ 21) Aid in learning important terms and facts of knowledge } \\
\hline \multicolumn{5}{|l|}{ 22) Prepare students for future study in these fields } \\
\hline \multicolumn{5}{|l|}{ 23) Learn how to communicate ideas in math/science } \\
\hline \multicolumn{5}{|l|}{ effectively } \\
\hline \multicolumn{5}{|l|}{ 24) Prepare students for standardized tests } \\
\hline \multicolumn{5}{|l|}{ 25) Learn about the relation between STEM subjects } \\
\hline \multicolumn{5}{|l|}{ 26) Connect math/science to students daily life issues } \\
\hline \multirow{2}{*}{\multicolumn{5}{|c|}{$\begin{array}{l}\text { 27) Make a connection between STEM subjects in problem } \\
\text { solving }\end{array}$}} \\
\hline & & & & \\
\hline \multicolumn{5}{|l|}{ 28) Effect on students' critical thinking and problem solving } \\
\hline \multicolumn{5}{|l|}{ 29) Increase measures of student achievement in STEM } \\
\hline subjects that are integrated & & & & \\
\hline
\end{tabular}




\section{Teaching the New Math and Science Subjects in a Classroom}

Please provide your opinion about each of the following statements:

\begin{tabular}{l}
\hline Statement \\
30) Teachers are well prepared and equipped to teach the new \\
math/science curriculum \\
31) Teachers on your school regularly observe each others classes \\
as a part of sharing and improving instructional strategies \\
32) The new Math and science curriculum is contributed to \\
STEM education \\
33) Teachers' development programs and work shops were \\
offered before new curriculum implementation \\
34) The new curriculum offers students better learning \\
opportunities \\
35) The new curriculum is more relevant to students lives and \\
21century demands \\
36) The new curriculum is considered as an improvement in \\
Saudi Arabia's education \\
37) The new curriculum challenges students by offering complex \\
problems related to real-world scenarios \\
38) STEM education has been integrated as something other than \\
adding additional science and mathematics instruction/courses \\
into your school
\end{tabular}

\section{E. Open Ended Questions Regarding the Newly Integrated Math and Science Curriculum}

39) As a teacher are you familiar with the concept "STEM education"?

40) Do you believe that the new curriculum is a form of STEM education?

41) What are the challenges facing teachers in teaching the new math and science curriculum as a form of integrating STEM education into schools?

41) Do you believe that the new curriculum improves the standards of education in Saudi? Please answer with yes or no and explain.

42) From an educational point of view, which do you think is more beneficial to students the old or new math and science curriculum?

\section{Copyrights}

Copyright for this article is retained by the author, with first publication rights granted to the journal.

This is an open-access article distributed under the terms and conditions of the Creative Commons Attribution license (http://creativecommons.org/licenses/by/4.0/). 